\title{
'The debatable territory where geology and archaeology meet': reassessing the early archaeobotanical work of Clement Reid and Arthur Lyell at Roman Silchester
}

Article

Accepted Version

Lodwick, L. A. (2017) 'The debatable territory where geology and archaeology meet': reassessing the early archaeobotanical work of Clement Reid and Arthur Lyell at Roman Silchester. Environmental Archaeology: the Journal of Human Palaeoecology, 22 (1). pp. 56-78. ISSN 1461-4103 doi: https://doi.org/10.1080/14614103.2015.1116218 Available at https://centaur.reading.ac.uk/54531/

It is advisable to refer to the publisher's version if you intend to cite from the work. See Guidance on citing.

Published version at: http://www.tandfonline.com/doi/abs/10.1080/14614103.2015.1116218

To link to this article DOI: http://dx.doi.org/10.1080/14614103.2015.1116218

Publisher: Maney Publishing

All outputs in CentAUR are protected by Intellectual Property Rights law, including copyright law. Copyright and IPR is retained by the creators or other copyright holders. Terms and conditions for use of this material are defined in the End User Agreement. 


\section{www.reading.ac.uk/centaur}

\section{CentAUR}

Central Archive at the University of Reading

Reading's research outputs online 
Lodwick, L. A. (2016). "The debatable territory where geology and archaeology meet": reassessing the early archaeobotanical work of Clement Reid and Arthur Lyell at Roman Silchester. Environmental Archaeology DOI 10.1080/14614103.2015.1116218

\section{Introduction}

The study of archaeological plant remains from Silchester by Clement Reid and Arthur Lyell (1899-1909) was the first large scale archaeobotanical work to take place within Britain, around 70 years before the advent of systematic sampling for plant macrofossils. They produced the first archaeobotanical evidence for the presence of Roman introductions in Britain, both of new plant foods such as medlar (Mespilus germanica) and new wild plants such as corncockle (Agrostemma githago) (Robinson 2012). At the time of Reid's death, his work at Silchester was merely referred to as "the debatable territory where geology and archaeology meet" (Anon 1916), and since then, no reanalysis of the plant remains has been undertaken to assess the accuracy of his identifications.

The Roman town of Silchester had already been the subject of antiquarian interest for several centuries (Hingley 2012) when the Society of Antiquaries undertook the complete excavation of the Roman town from 1890-1909 (Boon 1974). The antiquarian excavations at Silchester took place in a period when the opportunistic analysis of visible plant remains from excavations was undertaken by botanists. Such investigations occurred with material from Roman burials (Gage 1839), Ancient Egyptian tombs (Schweinfurth 1884) and Pompeii (Wittmack 1903). A notable exception to these sporadic studies was the detailed work of the palaeobotanist Oswald Heer on the Swiss lake villages, excavated in the mid nineteenth century (Jacomet and Kreuz 1999, 13-15).

However, from 1899, plant remains began to be recovered by the sieving of waterlogged sediment from numerous pits and wells excavated within Silchester (Robinson 2012). The identified plant remains were published in short notes appended to the end of the annual excavation reports published in Archaeologia (Reid 1901-1909). Following the postwar period, the analysis of 
plant remains from post glacial sites in Britain continued only on an occasional basis, primarily through the study of charred plant remains undertaken by Percival and Helbaek (Percival 1934; Helbaek 1952). It was not until the later 1970s that on-site sampling for archaeobotanical remains began again in Britain (Jones 1978; Lambrick and Robinson 1979; Kenward and Hall 1995). This followed the commencement of interdisciplinary analyses on archaeological sites in Germany form the 1960s, as at Feddersen Wierde (Jacomet and Kreuz 1999), and the flotation revolution in the Near East (French 1971; Williams 1973).

Due to this hiatus in on-site archaeobotanical sampling, the plant remains reported by Reid remained an important dataset for understanding Holocene vegetation within Britain well into the twentieth century (Godwin 1975) until the widespread development of archaeobotany from the 1970s onwards (Van der Veen et al. 2007). Attention has been drawn to the importance of this pioneering study (Jones 2000; Robinson 2012) and considering the extensive excavation and archaeobotanical analysis currently ongoing in Insula IX (Robinson 2012), it was considered timely to return to the earliest archaeobotanical work undertaken at Silchester: first, in order to assess the validity of the identifications, and second, to explore whether any further spatial or chronological information regarding the distribution of plants throughout the town could be recovered. Furthermore, as one of the earliest archaeobotanical studies in Britain, it is important to assess the character of the work at Silchester and its contribution, or lack thereof, to the development of archaeobotany within Britain.

\section{History of the Collection}

\section{Silchester - Calleva Atrebatum}

Silchester, or Calleva Atrebatum, is located halfway between the modern towns of Reading and Basingstoke in central-southern England (Figure 1). A Late Iron Age oppidum was present from c. 25 BC (Fulford and Timby 2000) and, following a period as part of a client kingdom, the settlement became a civitas capital in the later first century AD (Fulford 2003; 2008). The city was 
abandoned at some point between the fifth and seventh century AD and has remained a greenfield site ever since (Fulford 2012).

\section{History of investigation}

Silchester has been subject to antiquarian interest from the sixteenth century onwards (Boon 1974; Fulford 2007; Hingley 2012). The most extensive and detailed investigations were the Society of Antiquaries excavations (18901909), instigated by George E. Fox and W. H. St. J. Hope, with the support of Pitt Rivers (Fox and Hope 1891). The excavators focused on one area of the town each season, digging a series of trenches, and only opening up wider areas when masonry structures, pits or wells were encountered (Figure 2) (Fulford et al. 2002). Annual reports were issued in the journal Archaeologia. The full results of the Society of Antiquaries excavations were never published, although the sculpture and architectural stone (Cunliffe and Fulford 1982), mosaics (Neal and Cosh 2009), pottery (May 1916; Timby 1989; Timby 2012), quernstones (Shaffrey 2003) and shale (Lawson 1976) were later reported on. Subsequently, research excavations have taken place in various parts of the town and the site is a Scheduled Ancient Monument (Fulford and Timby 2000; Fulford et al. 2006).

\section{Recovery, identification and consultation of plant remains}

Clement Reid was a geologist and palaeobotanist, most renowned for his work on quaternary and Pliocene deposits from Norfolk, conducted alongside his wife Eleanor (O'Connor 2007). The earliest record of Reid's involvement in the Silchester excavations was the inclusion of a taxa list from Silchester in his seminal Origin of the British Flora (Reid 1899). A description of the methods used to extract plant remains is provided in a note written from the antiquarian Arthur Lyell to John Ward, the curator of the Cardiff Museum (Boon 1975). Lyell was the nephew of the geologist Sir Charles Lyell (Mosley 2003, 2434), and had studied at Cambridge University (Anon.1882). In his letter to Ward, Lyell emphasised the importance of taking samples from undisturbed deposits with clean tools, and marking the pit number and depth at which the sample was taken. He indicated that the samples were then gently wet-sieved through fine wire sieves no coarser than 1/16 inch (1.6mm), 
and seeds were collected by eye from a sub-sample of the dried material (Boon 1975). During this procedure, Lyell also collected insect remains, which were sent to C.O Waterhouse at the British Museum (Amsden and Boon 1975).

From 1900 onwards (Reid 1901), a section near the end of each annual excavation report was present detailing the plant remains identified, varying from several pages with sample lists per feature, to just a few sentences noting the additions of new taxa (Reid 1901-1909). Table 1 summarises the archaeobotanical data published in these reports by Reid, listing which excavation season and corresponding Insulae each taxa was identified from. The Latin and common names used by Reid have been followed, and any mention of the abundance of certain taxa has been indicated within the table. The Insulae, or town blocks, excavated from 1901 onwards were mainly situated in the northern and eastern areas of the town (Figure 1). Thomson summarised the results of the botanical studies in the 1920s, highlighting the imported foods such as fig and medlar, and adding that selected specimens had been labelled for exhibition and added to the Silchester Collection in Reading Museum (Thomson 1924, 660).

Most of the plant remains were presented to Reading Museum on Lyell's death in 1925 by his widow Florence (Amsden and Boon 1975, 129), after the cataloguing of the Society of Antiquaries material had already been undertaken by Fox and others (Greenaway pers. comm.). The collection has been consulted several times during the twentieth century. Percival viewed the record of Triticum sativum L. (Jones 2000) as part of his research on ancient wheat in Britain (Percival 1934; Hillman 2001), and Jones visited the collection whilst he was studying archaeobotanical remains from the ForumBasilica excavations at Silchester. He praised the early work conducted by Reid and Lyell, yet noted that the appearance of the material was inconsistent with ancient waterlogged plant remains, and raised the possibility that much of it represented intrusive modern material (Jones 1985; 2000). The disparate storage of part of the museum's collection during this period may explain the doubts raised by Jones (Greenaway pers. comm.). 


\section{Methodology}

The reassessment of the archived plant remains was conducted by the author from 2012 to 13 . The collection appeared to be relatively intact, although repackaging had taken place at some point, most probably by Boon in the 1950s when he undertook extensive reviews of the artefacts from the Society of Antiquaries excavations (Boon 1974). The plant remains, mainly seeds, had been dried, mounted on cardboard slides, and covered with a glass cover slip. Nearly all slides were labelled with their Latin binomial and common name. Some slides also provided the year of excavation, Insula, feature type and number, depth of sample and photograph number. The number of seeds per slide varied from 1 to 45 , although numerous seeds had been lost or damaged. Also present in the Silchester Collection is a sizeable reference collection of modern seeds and wood sections and archaeological wood and charcoal; these are not included in this paper.

The original identifications of all plant remains was confirmed or corrected. Identifications were checked against reference material from the Oxford University Museum of Natural History. Nomenclature follows Stace (1997). The taxonomic names used by Reid are also given. All available details of feature, year of excavation and Insula were recorded. It was evident that not all of the studied plant remains had been retained, as numerous taxa listed in the 1901-1909 excavation reports were absent from the collection (Reid 19011909). Further information regarding the Insulae and features from which the plant remains were recovered was established through consultation of the excavation reports, with limited phasing information provided by a recent reassessment of the ceramics (Timby 2012). A complete catalogue of every slide is provided in ESM Table 1, listing the taxa and common names written on the slide, the confirmed or amended identifications made by the author, the number of items present per slide, the plant part and the mode of preservation, and any further information given on the slide. A summary of the occurrence of each confirmed taxa is listed in Table 2, listing the total number of slides containing that taxa, the total number of seeds identified, and the year and Insulae that they were identified from. 


\section{Results}

The 284 slides and containers present in the Silchester Collection contained plant remains recovered from the 1899-1909 excavation seasons, with the majority deriving from excavation of the north-eastern Insulae 22 and 27 in 1901 (Hope and Reid 1902). This material also includes plant remains recovered during the unpublished excavations which took place in 1909 beside the city walls. At least 54 individual features are recorded as sampling locations on the slides. These are mainly pits and wells, but also include the town ditch, the bath drains and areas below floors (ESM Table 1). However, many slides are only labelled with the year of excavation. The majority of the seeds present had been preserved by anoxic waterlogging, which is consistent with the diverse assemblages of waterlogged plant remains recovered from wells and pits in Insula IX during the recent excavations (Robinson et al. 2006, Robinson 2011, Lodwick 2014, Lodwick 2015a). Three slides contained charred cereal grains and weed seeds. The small number of charred plant remains present may be due to a low density of charred plant remains in the archaeological deposits sampled by Lyell, or be a product of the recovery methods used. Many mineralised Prunus spp. (cherry/plum etc.) stones and Pyrus/Malus sp. (pear/apple) pips were present in unlabelled plastic boxes, and two slides of mineralised Anethum graveolens (dill) seeds from the 1900 and 1903 seasons were also present (Table 2).

Overall, 130 taxa were present in the Silchester collection and the annual reports, summarised in Table 2. Of these, 7 were present only in the collection, and 16 were published in the reports but absent from the collection. Of the identifications made by Reid, 83 were confirmed; 44 were confirmed to genus level, but could not be confirmed to species level due to the poor condition of the seeds; and 3 taxa were present but unlabelled. Just 9 taxa had been incorrectly identified by Reid. Items on one slide had been identified as Sinapsis alba (now Brassica alba - white mustard), from a well in Insula 22 excavated in 1901, but were actually fungal bodies (Figure 3). Chenopodium cf. hybridum had been identified by Reid as 
Chenopodium bonus-henricus, and Reid had named

Hyoscyamus niger as Solanum dulcamara. A stone of the evergreen shrub Prunus lusitanica (portugese laurel), identified from the 1904 excavations, could only be identified as Prunus sp., and did not have any of the defining features of $P$. lusitanica (Figure 4). A single seed labelled as Chaerophyllum aureum L. (Reid 1908) was reidentified as Scandix pectenveneris $\mathrm{L}$. This misidentification is common due to the miss-labelling of $S$. australis L. as $S$. pectin-veneris in botanic gardens, and subsequently in reference collections (Preston et al. 2004, 269; Robinson 2007). These mistakes are all understandable due to the similar appearances of the taxa involved, and the overall ability of Reid to identify plant macrofossils was excellent.

The potential presence of modern seeds in the collection, as raised by Jones (Jones 2000, 506) was difficult to assess due to the dried condition of the waterlogged plant remains. Many did appear genuinely ancient, due to the apparent lack of an embryo or endosperm, and a 'deflated' appearance (Robinson 1989, 79). The location of samples recorded on the slides indicates that these were usually taken from below the water table, such as "Pit III at 11' " (Anethum graveolens, 1903), where the risk of modern intrusion is lessened due to the absence of earthworm activity. Also, the careful sampling procedure described by Lyell (Boon 1975) shows that he was aware of the risk of contamination, and took steps to lessen this.

The description of some sampling locations, however, such as "Hole in courtyard of L shaped House. S W. corner of grass field 6!", (Spiraea ulmaria, 1907) does raise doubts as to whether the plant remains from these features were Roman or modern seeds. Overall, the similarities in the range of imported plant foods and taxa identified by Reid and Lyell to those identified recently from Insula IX (Robinson et al. 2006; Robinson 2011; Lodwick 2014, Lodwick 2015a), makes it likely that the majority of the plant remains did derive from the Late Iron Age and Roman occupation of the town. 
The taxa present included many cultivated plant foods. The flavourings Anethum graveolens (dill), Apium graveolens (celery) and Coriandrum sativum (coriander) were identified. One slide of coriander seeds was present from Insula 21, small house, 1900 (Figure 5). Slides containing numerous dill seeds are present dated as from 1900, 1902 and 1904. Dill was not identified until 1906, when Reid notes that "Attention was drawn last year to a peculiar seed allied to parsnip, which could not be satisfactorily identified. It has now been discovered that this seed, which occurs not uncommonly, and is generally associated with coriander, belongs to the dill." (Reid 1906, 164). Additionally, there was a single seed of Apium graveolens (celery), from Pit XVII Insula 23, which was in too poor condition to be confirmed, and two slides of the flavouring or weed Papaver somniferum (opium poppy), one of which was confirmed. It is likely that more seeds of these taxa were not found due to the relatively large aperture of sieve used $(1.5 \mathrm{~mm})$. Given the results from Insula IX (Lodwick 2014), the absence of Juncus ssp. must also be due to the sieve size, a conclusion also drawn in respect of Reid's work on Early and Mid Pleistocene sites (Turner and Gibbard 1996, 378). Seeds of the oil and fibre plant, Linum usitatissimum (flax) were identified from the 1901 excavations in the north-east of the town, and flax capsules from the 1899-1900 season; however these were both absent from the collection.

Reid's identification of the fruits Ficus carica (fig), Morus nigra (mulberry), Prunus avium (sweet cherry), Prunus domestica (bullace/plum) and Vitis vinifera (grape) were also all confirmed (Table 2). Two slides of fig seeds were present in the Silchester Collection, labelled as from the 1900 and 1902 excavations in the northern area of the town (Figure 6). The identification of two slides of mulberry pips was confirmed, both originating from the 1902 excavations in the eastern Insulae. A single slide of grape seeds was present in the collection, from Insula 23. Numerous Prunus avium stones were present. The only labelled stones derived from the 1907 excavations in the southern Insula 35. Stones of Prunus domestica ssp. insititia (bullace/damson) and Prunus domestica ssp. domestica (plum) were both present, but again, mostly unlabelled. A slide containing 12 stones of Prunus 
domestica ssp. insititia was labelled as Prunus domestica from the bath drains.

An important record is that of two stones of Mespilus germanica (medlar), both labelled as from 1904 (Figure 7), when Insulae 33, situated in the southeast of the town and containing the Public Baths (Boon 1974), was excavated. These two items remain the only identifications of medlar from Roman Britain (Pollman and Jacomet 2012). One cone and two collections of bracts and nutshells of Pinus pinea (stone pine) were present in the collection, but were unlabelled. There is no mention of these in the annual Archaeologia reports, but they were included in Boon's synthesis (Boon 1974, 165). Based on the presence of iron staining consistent with waterlogging, they appear to be genuine archaeological material (Robinson pers. comm.). Potential wild plant foods are the fruits of Crataegus sp. (hawthorn), Fragaria vesca (wild strawberry), Prunus spinosa (sloe), Rubus fruticosus agg. (bramble) and Sambucus nigra (elder), and the flavourings Papaver somniferum (opium poppy) and Brassica nigra (black mustard). Corylus avellana, presumably hazel nutshell, was identified by Reid from the 1901 and 1902 excavations, but was absent from the collection.

Beyond the evidence for new plant foods, some of the taxa identified at Silchester are currently classified as archaeophytes introduced to Britain during the Roman period (Preston et al. 2004; Witcher 2013). Reid identified Malva rotundifolia in his initial study of the northern Insulae (Reid 1901, 254). Preston et al. have stated that this identification should be regarded in modern nomenclature as the archaeophyte Malva neglecta (dwarf mallow) introduced in the Roman period (Preston et al. 2004, 267). A single slide in the collection contained two seeds which could only be confirmed as Malva sp. Lamium purpureum (red dead-nettle) was again identified from the northern Insulae (Reid 1902, 256). One slide was present in the collection, labelled as Pit V, 1903. The single seed could only be confirmed as Lamium sp. Reid also identified the arable weed Agrostemma githago (corncockle), now known to be an Iron Age introduction (Campbell 2000), from the northern Insulae (Reid 
1901, 254). The identification of two seeds in the collection, labelled as coming from Pit No 1, 1900, was confirmed.

Chenopodium murale (nettle-leaved goosefoot) was identified in 1907 (Reid $1908,210)$. The contents of two slides in the collection could only be reidentified as Chenopodium sp. Chenopodium bonus-henricus (good-kingHenry) was identified in 1900 (Reid 1901, 256). The corresponding slide in the collection, labelled pit XIX, 1900, was reidentified as Chenopodium cf. hybridum (maple-leaved goosefoot). The contents of another slide, labelled as Chenopodium bonus-henricus, well, Insula 22, was reidentified as Atriplex sp. (oraches). This slide must correspond with one of the finds reported in 1902 (Reid 1901). Reid also identified Chenopodium hybridum (Reid 1903). The respective slide in the collection, labelled as well B, 1902, was confirmed as containing Chenopodium hybridum. Reid identified Onopordum acanthium from the 1905 excavations of Insulae V and VI (Reid 1906). This identification was confirmed, the slide labelled "Pit IX No 5, at 5'6" ". Coronopus squamatus was identified by Reid from 1900 and1901 excavations, and the identification of seeds from both was confirmed in the collection. As discussed above, seeds of the archaeophyte Scandix pecten-veneris were identified. The slide was not labelled with a year or Insulae, but must be that reported by Reid as C. aureum in 1907 (Reid 1908). Finally, leaves of Buxus sempervirens (box) were identified by Reid from several Insulae (Reid 1903; 1909), and two slides in the collection were confirmed as box leaves. Hence, some identifications of archaeophytes stand as genuine data points, yet the poor condition of many seeds hinders confirmation.

Charred cereal grains from two pits in the north-east and south-east areas, were reidentified by the author as Triticum spelta. Reid claimed to have identified Pisum sativum (pea) from the centre of the town (Reid 1908, 211), yet only a box of unlabelled charred Vicia faba var. minor (celtic bean) was present in the collection.

The range of wild taxa present include plants of disturbed nitrogen-rich ground (Atropa belladonna, Ballota nigra, Urtica dioica, Urtica urens) and grassland 
(Filipendula ulmaria, Potentilla erecta, Prunella vulgaris). There is also a diverse range of wetland taxa (Reid 1901, 253),

including Bidens tripartita, Myosoton aquatica and Persicaria hydropiper), and bracken (Pteridium aquilinum fronds), which grows in heathland and woodland. The limited number of records documenting sampling locations, as well as the absence of information on sample size, mode of preservation, or the number of identifications made per sample, hinders the investigation of the composition of individual samples.

\section{Discussion}

\section{Reassessment of Reid and Lyell's study}

Characterising the archaeobotanical fingerprint of a Roman town was a significant accomplishment for Reid and Lyell. Overall, their identification skills were accurate and the majority of the plant remains were correctly identified. Reid had built up an extensive seed reference collection to assist him in palaeobotanical identification (Reid 1899), which is housed today alongside the archaeobotanical material. Despite this, Reid did not recognise that the mineralised plant remains were composed of different material to the more frequent waterlogged plant remains. Many mineralised items in the collection were unlabelled, but the range of taxa bear a strong similarity to the contents of a potential latrine excavated in 1907 in House 3, Insula XXXV. Described by Reid as "manure-pit below XXXV.I", it contained "the seeds of some 40 plants, including apple, blackberry, cherry, fig, large plum, poppy ... and slow" (sic) (Reid 1908, 212). The characteristics of mineralised plant remains were not set out until the late 1970s (Green 1979). Reid's identification of the charred plant remains was incorrect. The few cereal grains recovered were identified as Triticum sativum $\mathrm{L}$., the earlier name for Triticum aestivum $\mathrm{L}$. (bread wheat) (Zohary et al. 2012, 48), but have been reidentified as Triticum spelta and cf. Bromus secalinus.

Whilst the identification skills of Reid and Lyell were accurate, the conclusions drawn lacked the understanding of taphonomy that archaeobotanists have 
today. Reid's main intention was to establish the long term floristic history of the British Isles (Reid 1899), with the aim to identify climatic phases from plant macrofossils (O'Connor 2007, 334). The only data published were thus lists of taxa, with no quantitative data included.

Plant remains present were often also interpreted as direct evidence for the surrounding vegetation and settlement activities. For instance, in 1904 Reid suggested that "much of the surrounding country was probably covered in bracken", on the basis that bracken was identified (Reid 1901, 254) and due to the presence of several aquatic taxa, that there was a pond nearby (Reid $1906,164)$. Furthermore, the presence of abundant arable weeds in samples from the northern Insulae was interpreted as evidence of on-site cropprocessing (Reid 1901, 253). A strong emphasis was placed on the identification of the poisonous plants Atropa belladonna and Solanum nigrum in the assemblage (Reid 1901, 253; Reid 1902, 34), although Reid later concluded that the latter were derived from settlement vegetation, and that $A$. belladonna was used for cosmetic purposes (Reid 1903, 427).

Studies on the taphonomy of waterlogged plant remains have since shown that waterlogged plant assemblages recovered from wells generally derive from a mixed range of sources (Greig 1988), and in some circumstances a single activity can be identified as the source. The presence of grassland and wetland taxa in Reid's assemblage raises the likelihood of "stable manure" being a potential source for some plant remains (Kenward and Hall 1997). The identification of plants used for medicinal or poisonous purposes remains challenging, and must be evaluated on a contextual basis (Hall and Kenward 2003). However, A. belladonna occurs often in archaeobotanical samples deriving from urban settlement vegetation (Greig 1996). Hence Reid's direct correlation between seeds identified and local vegetation or human activities, as outlined above, cannot be supported.

Reid did notice broad patterns in the archaeobotanical data, highlighting the variation between Pit XVII, Insula XXIII (1900) as "full of cultivated plants", such as fig, apple/pear and grape, and Pit XXVI (1900) with "no species used 
for food" (Reid 1901, 252). Reid suggested the possibility of assessing variations in the urban environment and status differentiation between households on the basis of his archaeobotanical data (Reid 1901, 252), but these optimistic statements were never realised. Despite producing the first archaeobotanical evidence for imported plant foods in Roman Britain, discussion is usually limited to classifying the plant foods as introductions (Reid 1901, 252), and by 1907 the length of the archaeobotanical report had decreased to four sentences (Reid 1907).

\section{Plant foods}

Due to the overall accuracy of Reid's identifications, we can accept the majority of the dataset as accurate, and compare it against the wealth of archaeobotanical now available from research and developer-funded excavations in Britain (Van der Veen et al. 2007). The most significant aspect of this is the confirmed presence of a range of plant foods, introduced to Britain in the Roman period or shortly before (Van der Veen et al. 2008), at Silchester. The identification of these cultivated plant foods, alongside wild plant foods, is summarised by area and year of excavation in Table 3. The cultivated fruits present at Silchester, plum or bullace/damson, sweet cherry and apple/pear have since been found at all settlement types in Roman Britain, and are thought to have been cultivated in Britain in the later Roman period (Van der Veen et al. 2008). Meanwhile, fig, grape and mulberry have been largely restricted to excavations at other major Roman towns, such as London and York, and military sites (Van der Veen et al. 2008). Stone pine cones and nuts, only evidenced from the Silchester Collection and not reported by Reid, have been found from a range of site types in Roman Britain, but are commonly associated with ritualised deposits (Lodwick 2015b).

The find of a stone of medlar, identified from Insula XXXIII, has remained the only record from Roman Britain (Van der Veen et al. 2008). The medlar fruit tree originated from south-west Asia or south-east Europe, and various written sources attest to it's presence in the central Mediterranean by the first century AD (Pollman and Jacomet 2012). The first Swiss record was recently 
reported form the Roman vicus of Tasgetium, whilst several fruit stones have been identified from Roman towns in France and Germany (Pollman and Jacomet 2012). The restriction of medlar to Silchester indicates that the fruit was an exotic import in Roman Britain. Writing in the first century $A D$, Palladius described how medlar fruits could be preserved in honey (Pollman and Jacomet 2012) suggesting a possible mechanism for their transport and consumption at Silchester, although local cultivation cannot be ruled out. The find of medlar from Roman Silchester correlates with the restriction of imported exotic plant foods to major towns and military establishments (Van der Veen et al. 2008).

The identification of the flavourings celery, coriander and dill at Silchester has been repeated at many site types across Roman Britain, where dill and coriander are some of the most common new plant foods (Van der Veen et al. 2008). The pulses and oil crops, represented by single identifications by Reid of flax and the reidentification of celtic-bean from the collection, have not been included in the recent review of plant foods in Britain (Van der Veen et al. 2008). However, flax has been observed as a common find in towns and rural settlements in Roman Britain beyond Silchester (Greig 1991, 311). In contrast, celtic bean has been observed as infrequent in the Roman period (Greig 1991, 311).

The verification of the numerous plant foods identified by Reid does raise the possibility of investigating their spatial and chronological distribution at Silchester. Unfortunately, very few plant foods are from samples from features which have been retrospectively dated by ceramics (Timby 2012) (ESM Table 1). Additionally, the number of seeds and fruit stones per slide appears to be a product of the slides being mounted for display (Thomson 1924, 660), as many are arranged in symmetrical patterns. The high numbers of some seeds, such as fig (Ficus carica L., 1900, 21 seeds), however, does show that they were abundant in some samples. The number of slides present in the collection is also unlikely to be related to any variation in frequency in the samples studied. The most common taxa, Anethum graveolens, is represented by 7 slides from 4 different seasons. This is most likely due to 
Reid's struggles to correctly identify the seed until 1906 (Reid 1905, 368; Reid 1906).

Further obscuring the possibility of assessing the overall distribution of plant foods across the town is the fact that taxa were not generally recorded in subsequent seasons once they had been initially identified. Those plant foods present in the initial study of the northern Insulae (Table 3), including celery and coriander, can be tentatively considered as more commonly consumed in Roman Silchester than those not identified by Reid until later seasons, such as mulberry in 1902 and medlar in 1904. However, the most reliable assessments of the abundance of different plant foods come from Reid himself, who gave rough abundances of plant foods in the initial study: "We now have found grape (very rare) ... blackberry (very abundant) ... fig (very rare)" (Reid 1901, 253). Occasional contextual information can provide glimpses into the settings where new plant foods were being consumed. Cherry, bullace/damson and sloe stones were labelled as originating from the "drain from bath", referring to the public baths located in Insula 33 (ESM Table $1)$.

Reid and Lyell's results show that the residents of Silchester had access to the typical range of foods being eaten in other major towns in Roman Britain, with the only very rare plant foods present being medlar and mulberry. There is no evidence from Reid's results that the exotics known from Roman London, such as black pepper, peach and pomegranate were consumed at Silchester, although these plants were exceptionally rare in London (Van der Veen et al. 2008).

The broad conclusions drawn from Reid and Lyell's work about the presence of cultivated plant foods in Silchester can be contrasted with the archaeobotanical data from the recent excavations in Insula IX, with the latter demonstrating how more detailed insights can be made into the use of plant foods when detailed sampling is undertaken of features assigned to chronological phases. First, the consumption of some of the introduced plant foods identified by Reid (celery, coriander), alongside olives, can be 
confirmed to have been taking place at Late Iron Age Silchester. The identification of these plant foods from two wells, closely dated by ceramics, provided the first evidence for the import of these foods before the Roman invasion of AD43 (Lodwick 2014). Second, intensive sampling within one Insula in one period (Early Roman Insula IX) has shown that some foods (coriander) are much more frequent than others (cherry) (Lodwick 2015a). Third, the additional foods cucumber, walnut and summer savory have been identified from the Late Roman occupation (Robinson et al. 2006). Furthermore, the recovery of charred plant remains, poorly represented in Reid's study, from the bulk flotation of a wide range of contexts, has shown the types of cereals consumed at Silchester (spelt wheat and six-row hulled barley), whilst quantitative analysis of the cereal items and arable weeds present in individual samples has informed upon cereal processing and cultivation (Lodwick 2015a).

\section{Ornamental plants and archaeophytes}

Several imported ornamental plants were also identified from Silchester. Box leaves were identified by Reid from Pit XIII in 1902 (Reid 1903) and, later, from the north-east Insulae (Reid 1909). The first of these were present in the collection, alongside some unlabelled leaves. There is limited evidence that there was a small-scale presence of box in prehistoric Britain (Di Domenico et al. 2012), although the use of box leaves is not evidenced in the archaeological record until the Roman period. Whilst box leaves have also been found in inhumation burials in Britain (Dobney et al. 1999, 29), their presence in urban waterlogged deposits serves as evidence for their use as ornamental plants, as at 1 Poultry, London, where box leaves were identified on a road surface adjacent to a building (Hill and Rowsome 2011, 200). Further evidence that box was grown in Roman Britain comes from the finds of leaves and twigs in York (Hall and Kenward 1990, 399), twigs in Bath (Davenport et al. 2007, 33) and charcoal from a villa at Frocester (Price 2000, 258). Reid also identified holly leaves from the 1905 excavations of Insulae $V$ and VI (Reid 1906). Elsewhere in Roman Britain, holly leaves have been found alongside other imported evergreens, and hence it has been suggested that the shrub was used ornamentally in the Roman period (Dickson 1994). 
The reassessment of the Silchester Collection has also contributed evidence for the Roman date of introduction of other plants which occur as arable weeds or in vegetation associated with settlements (Table 4). Chenopodium hybridum is an important confirmation, as it is the only record reported by Preston et al. (2004). Both examples of $C$. hybridum in the Silchester Collection derived wells. The confirmation of the presence of Coronopus squamatus

adds to a substantial number of Roman records in Britain (Preston et al. 2004, 264), whilst the arable weeds Onopordum acanthium and Agrostemma githago, confirmed here as present in the Roman period, also have Iron Age records (Preston et al. 2004, 264, 268). The presence of the arable weed $S$. pecten-veneris contributes to a smaller number of Roman records. However, previous identification mistakes may have lead to an under recording of this species (Preston et al. 2004, 269). The presence of Chenopodium bonushenricus was not confirmed. There is disagreement over the status of this herbaceous perennial as an archaeophyte (Preston et al. 2004, 258). Other Roman British records are from Farmoor (Lambrick and Robinson 1979), York (Kenward et al. 1986) and Reid's work at Caerwent (Boon 1978). The presence of Chenopodium murale was also not confirmed, reducing the number of known Roman records to three (Tomlinson and Hall 1996), including Reid's work at Caerwent (Boon 1978). Hence the Roman date for the introduction of these two taxa should be treated cautiously.

\section{Reid and Lyell's legacy in Archaeobotany}

At his death, Reid was remembered for his work in geology and Quaternary palaeobotany (Anon 1917; Anon 1919), with this archaeobotanical study at Silchester described only as "The debatable territory where geology and archaeology meet" (Anon 1916). More recent commentary on Reid and Lyell's study describes it as "pioneering work" (Dyson 2006, 127) and "One of the most interesting aspects of the earlier investigations at Silchester" (Wacher 1995, 287). Reid and Lyell are considered as "pioneers in the field of archaeobotany" (Robinson 2012). Despite the limitations in data recording and interpretation, the scale, methodological accuracy and production of 
new archaeobotanical data at Silchester was unprecedented in Britain, and comparable only to the work of Heer in Switzerland, and yet it is often absent from discussions of the historical development of Archaeobotany (Renfrew 1973; Pearsall 1989, 3-6; Jacomet and Kreuz 1999).

This lack of acknowledgment is linked to the limited impact of Reid and Lyell's work on the development of the field of archaeobotany. The annual site reports published in Archaeologia had a "haphazard quality to the inclusion of specialist contributions" (Evans 2007, 287), with coherent specialist reports not standard practice in excavation reports until several decades later (Evans 2007).

Reid and Lyell did, though, continue to undertake sporadic archaeobotanical analyses at prehistoric and Roman sites in Britain, including waterlogged plant remains from pits and wells at Caerwent (1902-1909) (Reid and Lyell 1911; Boon 1978), a ditch at Canon St, London (Norman and Reader 1906) and a well at the Roman fort at Pevensey, Sussex (Salzmann 1908, 134). Reid was also on the excavation committee of the Glastonbury Lake village (Coles 2004), and continued to examine botanical material sent to him from excavations, such as box leaves from a Roman child inhumation burial at Cann, Dorset (Gray 1918). Lyell continued to undertake archaeobotanical work independently, producing reports on plant macrofossils from Roman London (Lyell 1912) and Sussex (Couchman 1914). Eleanor Reid conducted internationally renowned work on Pleistocene and Tertiary palaeobotanical remains alongside her husband, continuing after his death (Reid and Reid 1915; Reid and Chandler 1933; Creese and Creese 2006).

Despite this, there was no long term impact in terms of continuation of the sampling and sieving of anthropogenic waterlogged sediments from archaeological sites after Reid, and later Lyell, had passed away. Following the development of pollen analysis in the 1920s, the application of plant macrofossil analysis declined in Britain (Birks and Birks 2000). When the Fenland Research Committee was founded at the University of Cambridge in 
1932, there was no continuation in personnel from those who had worked with Reid at Hoxne, Swanscombe or Silchester (Smith 1997; O'Connor 2007), and the committee was focused on investigating prehistoric archaeology.

The Subdepartment of Quaternary Research at the University of Cambridge, founded in 1948, was focussed on the glacial and post-glacial prehistoric period (West 2014, 85), and Harry Godwin, and later Richard West, were both aware of the pioneering work of the Reids (Turner and Gibbard 1996). The data from Reid's Origin of the British Flora formed the foundation of Godwin's Quaternary plant database (West 2014, 82). Camilla Dickson continued work on plant macrofossils within the Subdepartment as a technician in the 1950 s until 1963 (West 2014, 70), and later undertook important archaeobotanical research focussing on Scotland (Dickson and Dickson 2000). Jim Dickson conducted research on bryophytes in the 1960s (West 2014, 69, 85). Macrofossil work increased in scale in the 1970s through the work of Gay Wilson, who researched Iron Age and Roman plant macrofossils whilst employed as a research assistant to West (Wilson 1979; West 2014, 119). Despite this limited continuation in Holocene macrofossil studies, none of the post-war urban rescue excavations in the Roman towns of Britain included any systematic archaeobotanical sampling (Fox 1952; Grimes 1968; Holbrook 2008).

The Silchester dataset did, however, form the foundation of Roman archaeobotanical knowledge for much of the twentieth century (Robinson 2012). Comparison of the antiquarian dataset with more recently procured data allowed the key trends of exotic plant foods in towns, the trade in plant foods, and the existence of Roman horticulture (Murphy 1977; Willcox 1977), as well as viticulture (Williams 1977) and Roman ornamental gardens (Dickson 1994) to be established. The Silchester dataset has also contributed to new directions in archaeology, featuring in Fulford's analysis of deposition in Roman wells (Fulford 2001).

The impact of the results of Reid and Lyell's work on the field of Roman archaeology however, remained, limited. The discussion of plant foods other 
than cereals was infrequent in the major synthetic works of the twentieth century, being neglected by Collingwood (1923), Richmond (1963) and Millett (1990). Applebaum, undertaking the first focused study on food in Roman Britain, did draw on Reid's Silchester dataset, including mention of medlar, mulberry and flax (Applebaum 1972, 108-121), and this discussion was drawn upon by Frere, who listed vegetables, fruits and legumes alongside cereals in Britannia $(1967,179)$, but it was not until the 1990s that the study of food consumption rose to prominence in Roman archaeology, with notable studies drawing on a range of artefactual, archaeobotanical and zooarchaeological data (Meadows 1994; Hawkes 2001; Cool 2006). Reid's work did, though, have an influence in popular archaeology, appearing in contemporary newspaper reports on the excavations (Anon 1900), and remaining the major archaeobotanical dataset referred to in popular Roman cookery books (Renfrew 1985; Alcock 2001).

\section{Conclusion}

The reassessment of the archaeobotanical remains collected from Roman Silchester by Reid and Lyell has shown that this work was accurate and largely systematic in terms of the sampling, processing and identification undertaken. Certified records of new plant foods, such as mulberry and medlar, contribute further to the understanding of food consumption and social access in Roman Britain. The lack of detailed records hindered the identification of any chronological or spatial distributions of plant foods, and Reid's interpretation suffered from a lack of understanding of preservation and taphonomy. The presence of several archaeophytes was also confirmed, contributing to the knowledge of vegetation history in Britain. Whilst this pioneering archaeobotanical work did not have any direct impact on the later development of archaeobotany, it did serve as an inspiration to those in the field (Robinson pers. comm.) and contributed to public understanding of Roman food.

\section{Acknowledgments}


The research for this paper was undertaken during an AHRC funded DPhil at the University of Oxford. Many thanks to Jill Greenaway, Collection Care Curator at Reading Museum, for providing access to and advice on the Silchester Collection. I am very grateful to Professor Mark Robinson for providing advice on the identifications and comments on the text, Professor Mike Fulford for providing advice on the text, and two anonymous reviewers for their constructive comments on a previous version of this paper.

\section{Bibliography}

Alcock, J. 2001. Food in Roman Britain. Stroud: Tempus.

Amsden, A. F. and Boon, G. C. 1975. C . 0 . Waterhouse's list of insects from Silchester (with a note on early identifications of insects in archaeological contexts). Journal of Archaeological Science 2, 129-136.

Anon. 1882. University Intelligence. Times June 3 1882, 9.

Anon. 1900. Silchester. Reading Mercury May 1900, 3.

Anon. 1916. Clement Reid, F.R.S. Nature 98, 312.

Anon. 1917. Obituary. Clement Reid, F.R.S., F.L.S., Etc. Geological Magazine 4, 47-48.

Anon. 1919. Clement Reid, 1853-1916. Proceedings of the Royal Society of London, Series B 90(634), 8-10.

Applebaum, S. 1972. Roman Britain, pp. 3-277 in Finberg, H. (ed.) The Agrarian History of England and Wales I. A.D. 43-1042. Cambridge: Cambridge University Press.

Birks, H. H. and Birks, H. J. B. 2000. Future uses of pollen analysis must include plant macrofossils. Journal of Biogeography 27(1), 31-35.

Boon, G. C. 1974. Silchester: The Roman Town of Calleva. Newton Abbot: David \& Charles.

Boon, G. C. 1975. Edwardian management and excavation costs in Britain. Antiquity 49, 51-54.

Boon, G. 1978. A comparative list of plant-remains from Caerwent, pp. 113119 in Boon, G. (ed.), Monographs and Collections. I Roman Sites. Cardiff: Cambrian Archaeological Association.

Campbell, G. 2000. Plant utilization: the evidence from charred plant remains, pp. 45-59 in Cunliffe, B. (ed.), The Danebury Environs Programme. The Prehistory of a Wessex Landscape. Oxford: Institute of Archaeology. 
Coles, B. 2004. The development of wetland archaeology in Britain: 150 years of lake-dwelling research, pp. 98-114 in Menotti, F. (ed.), Living on the Lake in Prehistoric Europe. London: Routledge.

Collingwood, R. G. 1923. Roman Britain. London: Oxford University Press.

Cool, H. 2006. Eating and Drinking in Roman Britain. Cambridge: Cambridge University Press.

Couchman, J. E. 1914. A Roman well at Hassocks. Sussex Archaeological Collections 56: 197-198.

Creese, M. R. S. and Creese, T. M. 2006. British women who contributed to research in the geological sciences in the nineteenth century. Proceedings of the Geologists' Association 117: 53-83.

Cunliffe, B. and Fulford, M. 1982. Corpus Signorum Imperii Romani (Corpus of Sculpture in the Roman World): Great Britain. Vol. 1, Fasc. 2: Bath and the Rest of Wessex. Oxford: Oxford University Press.

Davenport, P., Poole, C. and Jordan, D. 2007. Archaeology in Bath: Excavations at the New Royal Baths (the Spa), and Bellott's Hospital 19981999. Oxford: Oxford Archaeology.

Di Domenico, F., Lucchese, F. and Magri, D. 2012. Buxus in Europe: Late Quaternary dynamics and modern vulnerability. Perspectives in Plant Ecology, Evolution and Systematics 14(5), 354-362.

Dickson, C. 1994. Macroscopic fossils of garden plants from British Roman and Medieval deposits, pp. 47-72 in Moe, D., Dickson, J. and Jorgensen, P. M. (eds.), Garden History: Garden Plants, Species, Forms and Varieties from Pompeii to 1800. Rixensart: PACT Belgium.

Dickson, C. and Dickson, J. 2000. People and Plants in Ancient Scotland. Stroud: Tempus.

Dobney, K., Hall, A. and Kenward, H. 1999. It's all garbage ... A review of bioarchaeology in the four English colonia towns, pp. 15-35 in $\mathrm{H}$. Hurst, $\mathrm{H}$. (ed.), The Coloniae of Roman Britain: New Studies and a Review. Portsmouth: Journal of Roman Archaeology Supplementary Series 36.

Dyson, S. 2006. In Pursuit of Ancient Pasts: A History of Classical Archaeology in the Nineteenth and Twentieth Centuries. New Haven, CT: Yale University Press.

Evans, C. 2007. "Delineating objects": nineteenth-century antiquarian culture and the project of archaeology, pp. 267-305 in S. Pearce (ed.), Visions of Antiquity: The Society of Antiquaries of London 1707-2007. London: Society of Antiquaries. 
Fox, A. 1952. Roman Exeter. Manchester: Published for the University College of the South-west of England by Manchester University Press.

Fox, G. E. and Hope, W. H. St. J. 1891. Communication of 27th February 1890. Proceedings of the Society of Antiquaries London, Ser 213, 85-97.

French, D. H. 1971. An experiment in water-sieving. Anatolian Studies 21, 59-64.

Frere, S. 1967. Britannia: a History of Roman Britain. London: Routledge \& Kegan Paul.

Fulford, M. 2001. Links with the past: pervasive "ritual" behaviour in Roman Britain. Britannia 32, 199-218.

Fulford, M. 2003. Julio-Claudian and Early Flavian Calleva, pp. 95-104 in Wilson, P. (ed.) The Archaeology of Roman Towns. Oxford: Oxbow Books.

Fulford, M. 2007. The grand excavation projects of the twentieth century, pp. 353-381 in Pearce, S. (ed.), Visions of Antiquity: The Society of Antiquaries of London 1707-2007. London: The Society of Antiquaries of London.

Fulford, M. 2008. Nero and Britain: the palace of the client King at Calleva and Imperial policy towards the province after Boudicca. Britannia 39, 1-13.

Fulford, M. 2012. Calleva Atrebatum (Silchester, Hampshire, UK): An early medieval extinction, pp. 331-351 in Christie, N. \& Augenti, A. (eds.), Vrbes Extinctae. Farnham: Ashgate.

Fulford, M., Clarke, A. and Eckardt, H. 2006. Life and Labour in Late Roman Silchester: Excavations in Insula IX since 1997. London: Society for the Promotion of Roman Studies. Britannia Monograph Series No. 22.

Fulford, M., Clarke, A., Eckardt, H. and Shaffrey, R. 2002. Victorian excavation methodology: the Society of Antiquaries at Silchester in 1893. The Antiquaries Journal 82, 285-306.

Fulford, M. and Timby, J. 2000. Late Iron Age and Roman Silchester: Excavations on the Site of the Forum Basilica, 1977, 80-86. London: Society for the Promotion of Roman Studies. Britannia Monograph Series No. 15.

Gage, J. 1839. A letter from John Gage, Esq. F.R.S., Director, to Hudson Gurney, Esq. F.R.S. V.P. \&c. containing an account of further discoveries of Roman sepulchral relics at the Bartlow Hills. Archaeologia 28(1), 1-6.

Godwin, H. 1975. The History of the British Flora. Cambridge: Cambridge University Press. 
Gray, H. S. G. 1918. Leaden Coffin found at Cann, near Shaftesbury. Proceedings of the Dorset Natural History and Antiquarian Field Club 38, 6873.

Green, F. J. 1979. Phosphatic mineralisation of seeds from archaeological sites. Journal of Archaeological Science 6, 279-284.

Greig, J. 1988. The interpretation of some Roman well fills from the midlands of England, pp. 367-381 in Küster, H. (ed.), Der Prähistorische Mensch und seine Umwelt. Stuttgart: Theiss.

Greig, J. 1991. The British Isles, pp. 299-334 in Van Zeist, W. Wasylikowa, K. and Behre, K-E. (eds.), Progress in Old

World Palaeoethnobotany. Rotterdam: A. A. Balkema.

Greig, J. 1996. Archaeobotanical and historical records compared: a new look at the taphonomy of edible and other useful plants from the 11th to the 18th centuries A.D. Circaea 12, 211-247.

Grimes, W. 1968. The Excavation of Roman and Mediaeval London. London: Routledge \& K. Paul.

Hall, A. and Kenward, H. 1990. Environmental Evidence from the Colonia: Tanner Row and Rougier Street. London: Council for British Archaeology.

Hall, A. and Kenward, H. 2003. Can we identify biological indicator groups for craft, industry and other activities? pp. 114-130 in Murphy, P. and Wiltshire, P.E.J (eds.), The Environmental Archaeology of Industry. Symposia of the Association for Environmental Archaeology 20. Oxford: Oxbow Books.

Hawkes, G. 2001. An archaeology of food: a case study from Roman Britain, pp. 94-103 in Davies, G., Gardner, A. and Lockyear, K. (eds.), TRAC 2000: Proceedings of the 10th Annual Theoretical Roman Archaeology Conference. Oxford: Oxbow.

Helbaek, H. 1952. Early crops in southern England. Proceedings of the Prehistoric Society 18, 194-233.

Hill, J. and Rowsome, P. 2011. Roman London and the Walbrook Stream Crossing: Excavations at 1 Poultry and Vicinity, City of London Part 2. London: MoLA Monograph 37.

Hillman, G. 2001. Archaeology, Percival, and the problems of identifying wheat remains, pp. 27-36 in Caligari, P. D. S. and Brandham, P. E. (eds.), Wheat Taxonomy: the Legacy of John Percival.

London: Linnean Society, Linnean Special Issue 3.

Hingley, R. 2012. "A place that a lover of antiquity will visit with great delight": from Caer Segonte to Calleva Atrebatum, pp. 23-29 in Fulford, M. 
(ed.), Silchester and the Study of Romano-British Urbanism. Portsmouth, Rhode Island: JRA Supplementary Series Number 90.

Holbrook, N. 2008. Excavations and Observations in Roman Cirencester 1998-2007 with a Review of Archaeology in Cirencester 1958-

2008. Cirencester: Cotswold Archaeology.

Hope, W. H. St. J. and Reid, C. 1902. Excavations on the site of the Roman city at Silchester, Hants, in 1901. Archaeologia 58(1), 17-36.

Jacomet, S. and Kreuz, A. 1999. Archäobotanik: Aufgaben, Methoden und Ergebnisse Vegetations- und Agrargeschichtlicher Forschung. Stuttgart: Utb Gmbh.

Jones, M. 1978. The plant remains, pp. 93-110 in Parrington, M. (ed.), The Excavation of an Iron Age Settlement, Bronze Age Ring-Ditches and Roman Features at Ashville Trading Estate, Abingdon (Oxfordshire) 1974-76. Oxford: Oxford Archaeological Unit.

Jones, M. 1985. The plant remains, pp. 33-35 in Fulford, M. (ed.), Guide to the Silchester Excavations. The Forum Basilica 1982-84. Reading:

Department of Archaeology, University of Reading.

Jones, M. 2000. The plant remains, pp. 505-512 in Fulford, M. and Timby, J., Late Iron Age and Roman Silchester: Excavations on the Site of the Forum Basilica, 1977, 80-86. London: Society for the Promotion of Roman Studies.

Kenward, H., Hall, A. and Jones, A. 1986. Environmental Evidence from a Roman Well and Anglian Pits in the Legionary Fortress. London : Published for the York Archaeological Trust by the Council for British Archaeology

Kenward, H. and Hall, A. 1995. Biological Evidence from 16-22 Coppergate. London: Council for British Archaeology.

Kenward, H. and Hall, A. 1997. Enhancing bioarchaeological interpretation using indicator groups: stable manure as a paradigm. Journal of Archaeological Science 24, 663-673.

Lambrick, G. and Robinson, M. 1979. Iron Age and Roman Riverside Settlements at Farmoor, Oxford. London: Council for British Archaeology Research Report 32.

Lawson, A. J. 1976. Shale and jet objects from Silchester. Antiquaries Journal 105, 241-276.

Lodwick, L. 2014. Condiments before Claudius: New Plant Foods at the Late Iron Age Oppidum at Silchester, UK. Vegetation History and Archaeobotany 23, 543-549. 
Lodwick, L. 2015a. An Archaeobotanical Analysis of Silchester and the Wider Region Across the Late Iron Age-Roman Transition. University of Oxford. Unpublished DPhil thesis.

Lodwick, L. 2015b. Identifying ritual deposition of plant remains: a case study of stone pine cones in Roman Britain, pp. 54-69 in Brindle, T. Allen, M., Durham, E. and Smith, A. (eds.) TRAC 2014: Proceedings of the TwentyFourth Annual Theoretical Roman Archaeology Conference. Oxford: Oxbow.

Lyell, A. 1912. Appendix 3: Seeds and wood found in various London Excavations p. 334, in Norman, P. and Reader, F. Further discoveries relating to Roman London, 1906-12. Archaeologia 63, 257-334.

May, T. 1916. The Pottery Found at Silchester. Reading:

E. Poynder, Holybrook P.

Meadows, K. I. 1994. You are what you eat: diet, identity and romanisation, pp. 133-140 in Cottam, S., Dungworth, D., Scott, S., and Taylor, J. (eds.), Proceedings of the Fourth Annual Theoretical Roman Archaeology Conference, Durham. Oxford: Oxbow.

Millett, M. 1990. The Romanization of Britain: an Essay in Archaeological Interpretation. Cambridge: Cambridge University Press.

Mosley, C. 2003. Burke's Peerage, Baronetage \& Knightage: Clan Chiefs, Scottish Feudal Barons. Wilmington: Burke's Peerage \& Gentry LLC.

Murphy, P. 1977. Early Agriculture and Environment on the Hampshire Chalklands: circa. 800 B.C. - 400 A.D. University of Southampton. Unpublished MPhil thesis.

Neal, D. S. and Cosh, S. R. 2009. Roman Mosaics of Britain, Vol. 3: SouthEast Britain. London: Illuminata Publishers for the Society of Antiquaries London.

Norman, P. and Reader, F. 1906. Recent discoveries in connection with Roman London. Archaeologia 60(1), 169-250.

O'Connor, A. 2007. Finding Time for the Old Stone Age: A History of Palaeolithic Archaeology and Quaternary Geology in Britain, 18601960. Oxford: Oxford University Press.

Pearsall, D. 1989. Paleoethnobotany: a Handbook of Procedures. San Diego: Academic Press.

Percival, J. 1934. Wheat in Great Britain. London: Duckworth.

Pollmann, B. and Jacomet, S. 2012. First evidence of Mespilus germanica L. (medlar) in Roman Switzerland. Vegetation History and Archaeobotany 21(1), 61-68. 
Preston, C., Pearman, D. and Hall, A. 2004. Archaeophytes in Britain. Botanical Journal of the Linnean Society 145, 257-294.

Price, E. 2000. Frocester, A Romano-British Settlement, its Antecedents and Successors. Volume 2: The Finds. Stonehouse: Gloucester \& District Archaeological Research Group.

Reid, C. 1899. The Origin of the British Flora. London: Dulau.

Reid, C. 1901. Notes on the plant remains of Roman Silchester, in Fox, G. E. and W. H. St. J., W. H., Excavations on the site of the Roman city at Silchester in 1900. Archaeologia 57(2), 252-6.

Reid, C. 1902. The plant remains in Hope, W. H. St. J., Excavations on the site of the Roman city at Silchester in 1901. Archaeologia 58(1), 34-36.

Reid, C. 1903. The plant remains in Hope, W. H. St. J., Excavations on the site of the Roman city at Silchester in 1902. Archaeologia 58(2), 425-428.

Reid, C. 1905. The plant remains in Hope, W. H. St. J. Excavations on the site of the Roman city at Silchester in 1903 and 1904. Archaeologia 59(2), 367368.

Reid, C. 1906. The plant remains in Hope, W. H. St. J., Excavations on the site of the Roman city at Silchester in 1905. Archaeologia 60(1), 164.

Reid, C. 1907. The plant remains in Hope, W. H. St. J., Excavations on the site of the Roman city at Silchester in 1906. Archaeologia 60(2), 449.

Reid, C. 1908. The plant remains in Hope, W. H. St. J., Excavations on the site of the Roman city at Silchester in 1907 Archaeologia 61(1), 210-13.

Reid, C. 1909. The plant remains in Hope, W. H. St. J., Excavations on the site of the Roman city at Silchester in 1908. Archaeologia 61(2), 485.

Reid, C. and Reid, E. 1915. The Pliocene Deposits of Britain. London : printed for Her Majesty's Stationery Office, by Eyre and Spottiswoode.

Reid, E. and Chandler, M. 1933. The London Clay Flora. London: Printed by order of the Trustees of the British Museum.

Renfrew, J. 1973. Palaeoethnobotany: the Prehistoric Food Plants of the Near East and Europe. London: Methuen.

Renfrew, J. 1985. Food and Cooking in Roman Britain: History and Recipes. London: English Heritage.

Richmond, I. A. 1963. Roman Britain. Harmondsworth: Penguin. 
Robinson, M. 1989. Seeds and other plant macrofossils, pp.78-90 in P. Ashbee, M. Bell and E. Proudfoot (eds.), Wilsford Shaft: Excavations 1960-62. London: Historic Buildings and Monuments Commission for England.

Robinson, M. 2007. The invertebrate and waterlogged plant remains, in Oxford Archaeology (South), The Eagle in the Landscape: The Archaeology of the Cotswold Water Park [data-set]. York: Archaeology Data Service [distributor] (doi:10.5284/1000197).

Robinson, M. 2011. The macroscopic plant and invertebrate remains, pp. 281291 in Fulford, M. and Clarke, A. (eds.) Silchester: City in Transition. London: Society for the Promotion of Roman Studies. Britannia Monograph Series No. 25.

Robinson, M. 2012. The place of Silchester in archaeobotany, pp. 213-225 in Fulford, M. (ed.), Silchester and the Study of Romano-British Urbanism. Portsmouth: JRA Supplementary Series Number 90.

Robinson, M., Fulford, N. and Tootell, K. 2006. Macroscopic plant remains, pp. 206-218 in Fulford, M., Clarke, A. and Eckardt, H. (eds.), Life and Labour in Late Roman Silchester: Excavations in Insula IX since 1997. London: Society for the Promotion of Roman Studies. Britannia Monograph Series No. 22.

Salzmann, L. 1908. Excavations on the site of the Roman fortress at Pevensey, 1907-08. Archaeological Journal 65, 125-135.

Schweinfurth, G.1884.

Über pflanzenreste aus Altägyptischen gräbern. Berichte der Deutschen Bota nischen Gesellschaft 2, 351-371.

Shaffrey, R. 2003. The rotary querns from the Society of Antiquaries' excavations at Silchester, 1890-1909. Britannia 34, 143-174.

Smith, P. J. 1997. Grahame Clark's new archaeology: the Fenland Research committee and Cambridge prehistory in the 1930s. Antiquity 71, 11-30.

Stace, C. 1997. New Flora of the British Isles. 2nd edition. Cambridge: Cambridge University Press.

Thomson, J. 1924. A Great Free City: the Book of Silchester; the Dramatic Complemental History of the Remarkable Atrebatian Stronghold which Became the Imperial Municipality called Calleva Atrebatum the Third Free City of the Romano-Britannic Province more Commonly Known as the Ruins of Silchester. London: Simpkin, Marshall, Hamilton, Kent \& co.

Timby, J. 1989. The pottery, pp. 80-124 in M. Fulford (ed.), The Silchester Amphitheatre: Excavations of 1979-85. London: Society for the Promotion of Roman Studies. Britannia: Monograph Series No. 10. 
Timby, J. 2012. The language of pots: an overview of pottery supply to Silchester and its hinterland, pp. 127-150 in M. Fulford (ed.), Silchester and the Study of Romano-British Urbanism. Portsmouth, Rhode Island: Journal of Roman Archaeology Supplementary Series, 90.

Tomlinson, P. and Hall, A. 1996. Review of archaeological evidence for food plants from the British Isles (ABCD). Internet Archaeology 1. doi:10.11141/ia.1.5.

Turner, C. and Gibbard, P. 1996. Richard West - an appreciation. Quaternary Science Reviews 15, 375-389.

Van der Veen, M., Livarda, A. and Hill, A. 2007. The archaeobotany of Roman Britain: current state and identification of research priorities. Britannia 38, 181210.

Van der Veen, M., Livarda, A. and Hill, A. 2008. New plant foods in Roman Britain - dispersal and social access. Environmental Archaeology 13(1), 1136.

Wacher, J. 1995. The Towns of Roman Britain. London: Book Club Associates.

West, R. 2014. Quaternary Research in Britain and Ireland: A History Based on the Activities of the Subdepartment of Quaternary Research, University of Cambridge, 1948-1994. Leiden: Sidestone Press.

Willcox, G. 1977. Exotic plants from Roman waterlogged sites in London. Journal of Archaeological Science 4(3), 269-82.

Williams, D. 1973. Flotation at Siraf. Antiquity 47, 288-292.

Williams, D. 1977. A consideration of the sub-fossil remains of "Vitis vinifera" L. as evidence for viticulture in Roman Britain. Britannia 8, 327-34.

Wilson, D. 1979. Horse dung from Roman Lancaster, a botanical report. Archaeo-Physika 8, 331-349.

Witcher, R. 2013. On Rome's ecological contribution to British flora and fauna: landscape, legacy and identity. Landscape History 34(2), 5-26.

Wittmack, L. 1903. Die in Pompeji gefundenen pflanzlichen reste. Botansiche Jahrbücher 33, 38-66.

Zohary, D., Hopf, M. and Weiss, E. 2012. Domestication of Plants in the Old World. $4^{\text {th }}$ edition. Oxford: Oxford University Press. 
Table 1: Summary of archaeobotanical results reported by Clement Reid in the annual reports published in Archaeologia (Reid 1901-1909), listed taxonomically. Nomenclature, Latin binomials and common names all follow Reid. Any indication given by Reid of seed abundance is displayed as $+=$ present, $-=$ rare, ${ }^{*}=$ abundant.

\begin{tabular}{|c|c|c|c|c|c|c|c|c|c|}
\hline & Year published & চ্口 & ণั & $\stackrel{\%}{\circ}$ & $\stackrel{\circ}{\circ}$ & $\stackrel{8}{\circ}$ & ڤิ & $\stackrel{\circ}{\circ}$ & $\stackrel{\circ}{\circ}$ \\
\hline & Year excavated & $\frac{8}{\frac{\circ}{\sigma}}$ & চீ & চீ & $\begin{array}{l}\text { ஸे } \\
\text { ᄋ̆ }\end{array}$ & $\stackrel{\text { L̊ }}{\circ}$ & $\stackrel{\circ}{\circ}$ & 옹 & $\stackrel{\infty}{\circ}$ \\
\hline & Insulae & $\begin{array}{l}\vec{x} \\
x \\
\dot{x} \\
\dot{x} \\
\dot{\overline{\bar{x}}} \bar{x} \\
\dot{x}\end{array}$ & $\begin{array}{l}\overline{\bar{x}} \\
\bar{x} \\
\overline{\bar{x}}\end{array}$ & 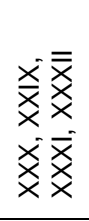 & $\overline{\overline{\bar{x}}}$ & $\begin{array}{l}> \\
>\end{array}$ & $\underset{\substack{x \\
x}}{\vec{x}}$ & $\begin{array}{l}\vec{x} \\
x \\
\dot{x} \\
\dot{\bar{x}} \\
\dot{x}\end{array}$ & $\begin{array}{l}\dot{x} \\
x \\
x \\
x= \\
x \\
x \\
x \\
x \\
x\end{array}$ \\
\hline Taxa & Common Name & & & & & & & & \\
\hline Pteris aquilina $\mathrm{L}$. & Bracken & + & & & & & & & \\
\hline Abies pectinata $\mathrm{L}$. & Silver Fir, casks only & + & & & & & & & \\
\hline Caltha palustris L. & Marsh Marigold & + & + & & & & & & \\
\hline Ranunculus acris L. & Meadow Buttercup & & & + & & & & & \\
\hline Ranunculus repens L. & Buttercup & + & + & & & & & & \\
\hline Ranunculus sardous Crantz. & & + & + & & & & & & \\
\hline Ranunculus parviflorus L. & & + & & & & & & & \\
\hline Ranunculus auricomus $\mathrm{L}$. & Goldielocks & & & + & & & & & \\
\hline Ranunculus scleratus L. & & + & & & & & & & \\
\hline Ranunculus lingua & Spearwort & + & & & & & & & \\
\hline Ranunculus flammula $\mathrm{L}$. & Lesser spearwort & + & & + & & & & & \\
\hline Ranunculus aquatilis L. & Water-crowfoot & & + & & & & & & \\
\hline Thalictrum flavum L. & Meadow-rue & + & & & & & & & \\
\hline Papaver somniferum L. & Opium Poppy & & & & + & & & + & \\
\hline Papaver rhoeas L. & Poppy & + & & & & & & & \\
\hline Papaver argemone $\mathrm{L}$. & Poppy & + & & & & & & & \\
\hline Fumaria officinalis L. & Fumitory & + & + & & & & & & \\
\hline Ficus carica L. & Fig & - & + & & & & & + & \\
\hline Morus nigra L. & Black Mulberry & & & & & & + & & \\
\hline Urtica dioica L. & Stinging Nettle & + & + & & & & & & \\
\hline Urtica urens L. & Nettle & & + & & & & & & \\
\hline Quercus robur L. & Oak & + & & & & & & & \\
\hline Alnus glutinosa L. & Alder & + & & & & & & & \\
\hline Corylus avellana $\mathrm{L}$. & Hazel & + & + & & & & & & \\
\hline $\begin{array}{l}\text { Chenopodium bonus- } \\
\text { henricus L. }\end{array}$ & Good-king-henry & + & + & & & & & & \\
\hline Chenopodium rubrum L. & Goose-foot & & + & & & & & & \\
\hline Chenopodium hybridum $\mathrm{L}$. & Goosefoot & & & + & & & & & \\
\hline
\end{tabular}




\begin{tabular}{|c|c|c|c|c|c|c|c|c|c|}
\hline Chenopodium murale L. & Nettle-leaved goose-foot & & & & & & & + & \\
\hline Chenopodium album $\mathrm{L}$. & Goosefoot & & & + & & & & & \\
\hline Atriplex patula L. & Orache & + & & & & & & & \\
\hline \multicolumn{10}{|l|}{ Atriplex sp. } \\
\hline Montia fontana $\mathrm{L}$. & Water Chickweed & + & & & & & & & \\
\hline Stellaria media Cyr. & Chickweed & + & + & & & & & & \\
\hline Stellaria graminea $\mathrm{L}$. & Lesser Stichwort & + & + & & & & & & \\
\hline Stellaria uliginosa Murray & & & & & & + & & & \\
\hline Stellaria aquatica Scop. & & & & & + & & & & \\
\hline Spergula arvensis $\mathrm{L}$. & Spurrey & + & + & & & & & & \\
\hline Lychnis flos-cuculi Linn. & Ragged Robin & + & & & & & & & \\
\hline Lychnis githago Linn. & Corn-cockle & * & & & & & & & \\
\hline Lychnis alba Mill & White Campion & + & + & & & & & & \\
\hline Polygonum amphibium & & & & & & & & & + \\
\hline Polygonum persicaria L. & Persicaria & + & & & & & & & \\
\hline Polygonum lapathifolium L. & & & & + & & & & & \\
\hline Polygonum hydropiper L. & Water-pepper & + & & & & & & & \\
\hline Polygonum aviculare L. & Knot-grass & + & + & & & & & & \\
\hline Polygonum convolvulus L. & Black bindweed & & + & & & & & & \\
\hline Rumex acetosella & Sheep-sorrel Dock & & & & & & & + & \\
\hline Rumex acetosa & Sorrel Dock & & & & & & & + & \\
\hline Rumex crispus L. & Docks & + & & & & & & & \\
\hline Rumex conglomeratus Murr. & Docks & + & & & & & & & \\
\hline Rumex obtusifolius L. & Docks & + & + & & & & & & \\
\hline Rumex viredis Sibth & Dock & & & + & & & & & \\
\hline Rumex & & & + & & & & & & \\
\hline Hypericum perforatum L. & St John's Wort & + & & & & & & & \\
\hline Malva sylvestris $\mathrm{L}$. & Mallow & + & + & & & & & & \\
\hline Malva rotundifolia L. & Mallow & + & + & & & & & & \\
\hline Viola & Violet & + & & & & & & & \\
\hline Bryonia dioica L. & White Bryony & + & + & & & & & & \\
\hline Thlaspi arvense L. & & + & + & & & & & & \\
\hline Senebiera coronopus Poir. & & + & + & & & & & & \\
\hline Brassica alba Boiss. & White Mustard & + & & & & & & & \\
\hline Brassica nigra Koch & Black Mustard & & & & & & + & & \\
\hline Brassica & & & + & & & & & & \\
\hline Raphanus raphanistrum L. & Wild Radish & & & & + & & & & \\
\hline Anagallis arvensis $\mathrm{L}$. & Pimpernel & + & & & & & & & \\
\hline Spiraea ulmaria L. & Meadow-sweet & + & & & & & & & \\
\hline Rubus fruticosus L. & Blackberry & * & + & & & & & + & \\
\hline Rubus idaeus L. & Raspberry & - & & & & & & & \\
\hline Potentilla tormentilla Neck. & Tormentil & + & + & & & & & & \\
\hline Fragaria vesca L. & Strawberry & - & & & & & & & \\
\hline Alchemilla arvensis Lam. & Lady's Mantle & + & & & & & & & \\
\hline Rosa canina L. & Dog Rose & + & & & & & & & \\
\hline Prunus spinosa L. & Sloe & * & & & & & & + & \\
\hline Prunus domestica L. & Damson & + & & & & & & & \\
\hline Prunus domestica L. & Large Plum, or Prune & * & & & + & & & & \\
\hline
\end{tabular}




\begin{tabular}{|c|c|c|c|c|c|c|c|}
\hline Prunus insititia L. & Bullace & * & & & & & \\
\hline Prunus avium $\mathrm{L}$. & Gean Cherry & * & & & & + & \\
\hline Prunus Iusitanica L. (?) & Portugal-laurel (?) & + & & & & & \\
\hline Prunus & & & + & & & & \\
\hline Pyrus Malus L. & Apple & + & & & & + & \\
\hline Pyrus germanica L. & Medlar & & & & - & & \\
\hline Crataegus oxyacantha $\mathrm{L}$. & Hawthorn & - & & & & & \\
\hline Pisum sativum & Garden Pea & & & & & + & \\
\hline Ilex aquifolium Linn. & Holly leaves & & & & + & & \\
\hline Buxus sempervirens L. & Box & & & + & & & + \\
\hline Vitis vinifera $\mathrm{L}$. & Grape & - & + & & & & \\
\hline Linum usitatissimum (?) & Flax (capsule) & - & & & & & \\
\hline Linum usitatissimum (?) & Flax & & + & & & & \\
\hline Hydrocotyle vulgaris L. & Penny-wort & + & & & & & \\
\hline Chaerophyllum aureum L. & Chervil & & & & & + & \\
\hline Caucalis anthriscus Huds. & & & & + & & & \\
\hline Coriandrum sativum $\mathrm{L}$. & Coriander & + & & & & & \\
\hline $\begin{array}{l}\text { Conopodium denudatum } \\
\text { Kock }\end{array}$ & Pig-nut & + & & & & & \\
\hline Oenanthe fistulosa L. & Water Dropwort & & & & & + & \\
\hline Oenanthe lachenalii & Water Dropwort & + & & & & & \\
\hline Aethusa cynapium & Fool's Parsley & + & & & & & \\
\hline Anethum graveolens L. & Dill & & & & + & & \\
\hline Conium maculatum $\mathrm{L}$. & Hemlock & + & + & & & & \\
\hline Apium graveolens $\mathrm{L}$. & Celery & + & & & & & \\
\hline Apium nodiflorum Reichb. & & & & + & & & \\
\hline Heracleum sphondylium L. & Hogweed & + & & & & & \\
\hline Daucus carota L. & Carrot & & & + & & & \\
\hline Atropa belladonna L. & Deadly Nightshade & * & + & & & & \\
\hline Solanum nigrum L. & Black Nightshade & & & + & & & \\
\hline Solanum dulcamara L. & Woody Nightshade & + & + & & & & \\
\hline Lithospermum arvense L. & Gromwell & & & + & & & \\
\hline Labiate (?) & & & + & & & & \\
\hline Stachys arvensis L. & & + & & & & & \\
\hline Ballota nigra L. & Black Horehound & + & & & & & \\
\hline Lamium purpurium $\mathrm{L}$. & Purple Dead-nettle & + & + & & & & \\
\hline Galeopsis tetrahit L. & Hemp-nettle & + & & & & & \\
\hline Ajuga reptans L. & Bugle & & & + & & & \\
\hline Prunella vulgaris $\mathrm{L}$. & Self-heal & + & + & & & & \\
\hline Calamintha arvensis Lam. & Calamint & & & + & & & \\
\hline Lycopus europaeus L & Gipsywort & + & & & & & \\
\hline Mentha aquatica $\mathrm{L}$. & Mint & + & & & & & \\
\hline Plantago lanceolata L. & Ribwort & + & & & & & \\
\hline Veronica hederaefolia L. & & + & + & & & & \\
\hline Galium palustre L. & Bedstraws & & & + & & & \\
\hline Galium verum Linn. & Bedstraws & & & + & & & \\
\hline Galium aparine Linn. & Bedstraws & & & + & & & \\
\hline Galium sp. & Bedstraws & + & & & & & \\
\hline
\end{tabular}




\begin{tabular}{|c|c|c|c|c|c|c|c|c|c|}
\hline Sambucus nigra L. & Elder & + & + & & & & & & \\
\hline Valeriana officinalis $\mathrm{L}$. & Cat's Valerian & + & + & & & & & & \\
\hline Valerianella dentata Poll. & Corn Salad & + & & & & & & & \\
\hline Arctium lappa L. & Burdock & + & & & & & & & \\
\hline Carduus crispus L. & Thistle & & & & & & + & & \\
\hline Carduus nutans L. & Thistle & + & & & & & & & \\
\hline Cricus lanceolatus Hoffn. & Thistle & + & + & & & & & & \\
\hline Cricus palustris Hoffn. & Thistle & & & & & + & & & \\
\hline Crisus arvensis Hoffn. & Thistle & & & + & & & & & \\
\hline Onopordum acanthium L. & Cotton Thistle & & & & & + & & & \\
\hline Serratula tinctoria L. & Saw-wort & & & + & & & & & \\
\hline Centaurea nigra L. & Knapweed & & & + & & & & & \\
\hline Lapsana communis L. & Nipplewort & & & + & & & & & \\
\hline Hypochaeris radicata & Cat's-ear & & & & & & & + & \\
\hline Leontodon autumnalis & Dandelion & & & & & & & + & \\
\hline Leontodon hispidus L. & Hawkbit & + & & & & & & & \\
\hline Picris hieracoides? & Hawkweed Picris & & & & & & & + & \\
\hline Sonchus palustris L. & Sowthisle & + & & & & & & & \\
\hline Sonchus arvensis L. & Corn Sowthistle & & & + & & & & & \\
\hline Sonchus oleraceus L. & Sowthistle & + & & & & & & & \\
\hline Sonchus asper Hoffn & Sowthistle & & & & & & & + & \\
\hline Taraxacum officinale Web. & Dandelion & & & + & & & & & \\
\hline $\begin{array}{l}\text { Chrysanthemum } \\
\text { leucanthemum }\end{array}$ & Oxeye & + & & & & & & & \\
\hline Bidens tripartita L. & Bur Marigold & + & & & & & & & \\
\hline Alisma plantago L. & Water-plantain & & & & + & & & & \\
\hline Eleocharis palustris $\mathrm{R}$. Br. & Sedges & + & & & & & & & \\
\hline Eleocharis acicularis Sm. & Sedges & + & & & & & & & \\
\hline Carex muricata Linn. & & & & & + & & & & \\
\hline Carex remota? L. & & & & & + & & & & \\
\hline Carex ovalis? Good. & & & & & + & & & & \\
\hline Carex dioica L. & Sedge & & & + & & & & & \\
\hline Carex riparia Curtis & Sedges & + & & & & & & & \\
\hline Carex panicea? L. & & & & & + & & & & \\
\hline Carex canescens (?) L. & Sedges & + & & & & & & & \\
\hline Carex & Sedges & + & + & & & & & & \\
\hline Triticum sativum $\mathrm{L}$. & Wheat & + & + & & & & & & \\
\hline
\end{tabular}


Table 2: Summary of plant remains present in the Reading Museum Silchester Collection, listing the identifications made by the author and Reid's original identifications. Explanation of the change in identification is summarised as follows: ${ }^{*}=$ change in nomenclature, $!=$ updated identification by author, ? = poor preservation limited identification. Further contextual information is available in ESM Table 1.

\begin{tabular}{|c|c|c|c|c|c|c|c|}
\hline Taxon (Stace 1997) & Taxon (Reid) & $\begin{array}{l}\text { Common Name } \\
\text { (Stace 1997) }\end{array}$ & $\begin{array}{l}\text { Change } \\
\text { in } \\
\text { Identific } \\
\text { ation }\end{array}$ & Insulae & $\begin{array}{l}\text { Year } \\
\text { excavat } \\
\text { ed }\end{array}$ & $\begin{array}{l}\text { No. of } \\
\text { slides }\end{array}$ & $\begin{array}{l}\text { Tota } \\
\text { I no. } \\
\text { of } \\
\text { item } \\
\text { s }\end{array}$ \\
\hline \multicolumn{8}{|l|}{$\begin{array}{l}\text { Waterlogged plant } \\
\text { remains }\end{array}$} \\
\hline Caltha palustris L. & Caltha palustris L. & Marsh-marigold & & & $\begin{array}{l}1900 \\
1901\end{array}$ & 3 & 2 \\
\hline Ranunculus acris L. & Ranunculus acris L. & Meadow Buttercup & & & 1903 & 1 & 1 \\
\hline Ranunculus cf. repens L. & $\begin{array}{l}\text { Ranunculus repens } \\
\text { L. }\end{array}$ & Creeping Buttercup & & 22 & $\begin{array}{l}1899 \\
1903\end{array}$ & 3 & 12 \\
\hline $\begin{array}{l}\text { Ranunculus sardous } \\
\text { Crantz }\end{array}$ & $\begin{array}{l}\text { Ranunculus sardous } \\
\text { Crantz. }\end{array}$ & Hairy Buttercup & & & 1900 & 1 & 2 \\
\hline $\begin{array}{l}\text { Ranunculus parviflorus } \\
\text { L. }\end{array}$ & $\begin{array}{l}\text { Ranunculus } \\
\text { parviflorus } \mathrm{L} .\end{array}$ & $\begin{array}{l}\text { Small-flowered } \\
\text { Buttercup }\end{array}$ & & & $\begin{array}{l}1900 \\
1908\end{array}$ & 2 & 2 \\
\hline Ranunculus lingua L. & $\begin{array}{l}\text { Ranunculus lingua } \\
\mathrm{L} \text {. }\end{array}$ & Greater Spearwort & & & 1906 & 2 & 11 \\
\hline Ranunculus flammula L. & $\begin{array}{l}\text { Ranunculus } \\
\text { flammula L. }\end{array}$ & Lesser Spearwort & & & 1902 & 2 & 8 \\
\hline $\begin{array}{l}\text { Ranunculus subg. } \\
\text { Ranunculus }\end{array}$ & $\begin{array}{l}\text { Ranunculus } \\
\text { auricomus L. }\end{array}$ & Buttercups & $?$ & & 1902 & 1 & 1 \\
\hline $\begin{array}{l}\text { Ranunculus subg. } \\
\text { Batrachium (DC.) A. } \\
\text { Gray }\end{array}$ & $\begin{array}{l}\text { Ranunculus } \\
\text { hederaceus }\end{array}$ & Water Crowfoots & $?$ & & 1909 & 1 & 3 \\
\hline $\begin{array}{l}\text { Ranunculus subg. } \\
\text { Batrachium (DC.) A. } \\
\text { Gray }\end{array}$ & $\begin{array}{l}\text { Ranunculus aquatilis } \\
\text { L. }\end{array}$ & Water Crowfoots & $?$ & & $\begin{array}{l}1905 \\
1909\end{array}$ & 2 & 6 \\
\hline Thalictrum flavum L. & Thalictrum flavum $\mathrm{L}$. & Common Meadow-rue & & & $\begin{array}{l}1900 \\
1902\end{array}$ & 3 & 5 \\
\hline Papaver somniferum L. & $\begin{array}{l}\text { Papaver somniferum } \\
\text { L. }\end{array}$ & Opium Poppy & & & 1904 & 1 & 3 \\
\hline Papaver argemone L. & Papaver argemone & Prickly Poppy & & & & 1 & 1 \\
\hline Fumaria sp. & Fumaria officinalis L. & Fumitories & $?$ & & $\begin{array}{l}1900 \\
1903\end{array}$ & 3 & 5 \\
\hline Morus nigra L. & Morus nigra L. & Mulberry & & & 1902 & 2 & 4 \\
\hline Ficus carica L. & Ficus carica L. & Fig & & 23 & $\begin{array}{l}1900 \\
1902 \\
\end{array}$ & 2 & 34 \\
\hline Urtica dioica L. & Urtica dioica L. & Common nettle & & 22 & - & 1 & 2 \\
\hline Urtica urens L. & Urtica urens L. & Small Nettle & & & - & 1 & 9 \\
\hline $\begin{array}{l}\text { Chenopodium } \\
\text { polyspermum L. }\end{array}$ & $\begin{array}{l}\text { Chenopodium } \\
\text { rubrum }\end{array}$ & $\begin{array}{l}\text { Many-seeded } \\
\text { Goosefoot }\end{array}$ & $!$ & & & 1 & 1 \\
\hline $\begin{array}{l}\text { Chenopodium hybridum } \\
\text { L. }\end{array}$ & $\begin{array}{l}\text { Chenopodium } \\
\text { hybridum }\end{array}$ & $\begin{array}{l}\text { Maple-leaved } \\
\text { Goosefoot }\end{array}$ & & & 1902 & 1 & 1 \\
\hline $\begin{array}{l}\text { Chenopodium cf. } \\
\text { hybridum } \mathrm{L} .\end{array}$ & $\begin{array}{l}\text { Chenopodium } \\
\text { bonus-henricus }\end{array}$ & $\begin{array}{l}\text { Maple-leaved } \\
\text { Goosefoot }\end{array}$ & $!$ & & 1900 & 1 & 2 \\
\hline Chenopodium album L. & Atriplex sp. & Fat-hen & $!$ & & 1902 & 1 & 7 \\
\hline Chenopodium album L. & $\begin{array}{l}\text { Chenopodium album } \\
\text { L. }\end{array}$ & Fat-hen & & & 1902 & 1 & 1 \\
\hline Chenopodium sp. & $\begin{array}{l}\text { Chenopodium } \\
\text { murale L. }\end{array}$ & Goosefoots & $?$ & & 1907 & 2 & 5 \\
\hline Chenopodiaceae indet. & $\begin{array}{l}\text { Chenopodium } \\
\text { rubrum }\end{array}$ & Goosefoot family & $?$ & & & 1 & 1 \\
\hline Atriplex sp. & Atriplex patula L. & Oraches & $?$ & & 1902 & 3 & 9 \\
\hline $\begin{array}{l}\text { Montia fontana ssp. } \\
\text { chondrosperma (Fenzl) } \\
\text { Walters }\end{array}$ & Montia fontana Linn. & Blinks & & 6 & $\begin{array}{l}1905 \\
1909\end{array}$ & 2 & 10 \\
\hline $\begin{array}{l}\text { Stellaria media gp. (L.) } \\
\text { Vill. }\end{array}$ & Stellaria media Cyn. & Common chickweed & & & . & 2 & 9 \\
\hline
\end{tabular}




\begin{tabular}{|c|c|c|c|c|c|c|c|}
\hline Stellaria graminea L. & Stellaria graminea $\mathrm{L}$. & Lesser Stichwort & & & 1902 & 3 & 6 \\
\hline $\begin{array}{l}\text { Myosoton aquaticum (L.) } \\
\text { Moench }\end{array}$ & $\begin{array}{l}\text { Stellaria aquatica } \\
\text { Scop. }\end{array}$ & Water Chickweed & * & & $\begin{array}{l}1903, \\
1905\end{array}$ & 2 & 3 \\
\hline Spergula arvensis L. & Spergula arvensis $\mathrm{L}$. & Corn Spurrey & & 22 & - & 1 & 1 \\
\hline Silene sp. & Lychnis alba Mill & Campions & *? & & 1900 & 1 & 4 \\
\hline Agrostemma githago $\mathrm{L}$. & $\begin{array}{l}\text { Lychnis githago } \\
\text { Linn. }\end{array}$ & Corncockle & * & & 1900 & 1 & 2 \\
\hline $\begin{array}{l}\text { Persicaria maculosa } \\
\text { Gray }\end{array}$ & $\begin{array}{l}\text { Polygonum } \\
\text { aviculare L. }\end{array}$ & Redshank & ! & 22 & 1902 & 1 & 1 \\
\hline $\begin{array}{l}\text { Persicaria maculosa } \\
\text { Gray }\end{array}$ & $\begin{array}{l}\text { Polygonum } \\
\text { maculatum D \& J. }\end{array}$ & Redshank & * & & 1902 & 1 & 1 \\
\hline $\begin{array}{l}\text { Persicaria maculosa } \\
\text { Gray }\end{array}$ & $\begin{array}{l}\text { Polygonum } \\
\text { persicaria L. }\end{array}$ & Redshank & * & & $\begin{array}{l}1900 \\
1906\end{array}$ & 2 & 2 \\
\hline $\begin{array}{l}\text { Persicaria maculosa } \\
\text { Gray }\end{array}$ & Polygonum & Redshank & * & & 1900 & 1 & 1 \\
\hline $\begin{array}{l}\text { Persicaria lapathifolia } \\
\text { (L.) Gray }\end{array}$ & $\begin{array}{l}\text { Polygonum } \\
\text { lapathyfolium L. }\end{array}$ & Pale Persicaria & * & & 1902 & 1 & 1 \\
\hline $\begin{array}{l}\text { Persicaria hydropiper } \\
\text { (L.) Delarbre }\end{array}$ & $\begin{array}{l}\text { Polygonum } \\
\text { hydropiper } \mathrm{L} \text {. }\end{array}$ & Water-pepper & * & & $\begin{array}{l}1900, \\
1902\end{array}$ & 3 & 6 \\
\hline $\begin{array}{l}\text { Polygonum aviculare } \\
\text { agg. L. }\end{array}$ & $\begin{array}{l}\text { Polygonum } \\
\text { aviculare L. }\end{array}$ & Knotgrass & & 22 & & 2 & 8 \\
\hline $\begin{array}{l}\text { Fallopia convolvulus (L.) } \\
\text { Á. Löve }\end{array}$ & $\begin{array}{l}\text { Polygonum } \\
\text { convolvulus L. }\end{array}$ & Black-bindweed & * & 27 & 1909 & 2 & 3 \\
\hline Rumex crispus L. & Rumex crispus $\mathrm{L}$. & Curled Dock & & & 1900 & 1 & 1 \\
\hline $\begin{array}{l}\text { Rumex conglomeratus } \\
\text { Murray }\end{array}$ & $\begin{array}{l}\text { Rumex } \\
\text { conglomeratus Murr. }\end{array}$ & Clustered Dock & & & 1902 & 2 & 5 \\
\hline Rumex sp. & Rumex sp. & & & 22 & 1900 & 2 & 6 \\
\hline Rumex sp. & Rumex crispus $\mathrm{L}$. & & $?$ & 26 & 1900 & 1 & 1 \\
\hline Rumex sp. & Rumex viredis Sibth & Docks & $?$ & & $\begin{array}{l}1902, \\
1906 \\
\end{array}$ & 2 & 5 \\
\hline Rumex obtusifolius L. & $\begin{array}{l}\text { Rumex obtusifolius } \\
\text { L. }\end{array}$ & Broad-leaved Dock & & & $\begin{array}{l}1900, \\
1902\end{array}$ & 3 & 5 \\
\hline Hypericum sp. & $\begin{array}{l}\text { Hypericum } \\
\text { perforatum Linn. }\end{array}$ & St. John's Wort & $?$ & & & 1 & 1 \\
\hline Malva sp. & Malva rotundifolia L. & Mallows & $?$ & 26 & 1900 & 1 & 2 \\
\hline Viola sp. & Viola & Violets & & 23 & 1900 & 1 & 3 \\
\hline Bryonia dioica Jacq. & Bryonia dioica L. & White Bryony & & & $\begin{array}{l}1900, \\
1903 \\
\end{array}$ & 2 & 2 \\
\hline Thlaspi arvense L. & Thlaspi arvense L. & Field penny-cress & & & $\begin{array}{l}1900, \\
1903\end{array}$ & 4 & 3 \\
\hline $\begin{array}{l}\text { Coronopus squamatus } \\
\text { (Forssk.) Asch. }\end{array}$ & $\begin{array}{l}\text { Senebiera } \\
\text { coronopus Poir. }\end{array}$ & Swine-cress & * & 22 & $\begin{array}{l}1900, \\
1901\end{array}$ & 2 & 7 \\
\hline Brassica sp. & Brassica campestris & Mustards & $?$ & 27 & & 1 & 4 \\
\hline $\begin{array}{l}\text { Brassica nigra (L.) } \\
\text { W.D.J. Koch }\end{array}$ & Brassica nigra Koch & Black Mustard & & 35 & $\begin{array}{l}1906, \\
1907\end{array}$ & 2 & 4 \\
\hline $\begin{array}{l}\text { Raphanus raphanistrum } \\
\text { L. }\end{array}$ & $\begin{array}{l}\text { Raphanus } \\
\text { raphanistrum L. }\end{array}$ & Radish & & & $\begin{array}{l}1902, \\
1904, \\
1908\end{array}$ & 3 & 4 \\
\hline cf. Primulaceae indet. & Anagallis tenella & Primrose family & $?$ & - & 1900 & 1 & 1 \\
\hline $\begin{array}{l}\text { Filipendula ulmaria (L.) } \\
\text { Maxim }\end{array}$ & Spiraea ulmaria L. & Meadowsweet & * & & 1907 & 1 & 5 \\
\hline Rubus fruticosus agg. L. & Rubus fruticosus $\mathrm{L}$. & Bramble & & & 1903 & 4 & 22 \\
\hline Potentilla sp. & Potentilla & Cinquefoils & & & 1900 & 1 & 1 \\
\hline $\begin{array}{l}\text { Potentilla cf. erecta (L.) } \\
\text { Raeusch }\end{array}$ & $\begin{array}{l}\text { Potentilla tormentilla } \\
\text { Neck. }\end{array}$ & Tormentil & $!$ & 22 & 1902 & 3 & 7 \\
\hline Fragaria vesca $\mathrm{L}$. & Fragaria vesca L. & Wild Strawberry & & & 1900 & 2 & 58 \\
\hline Aphanes arvensis L. & $\begin{array}{l}\text { Alchemilla arvensis } \\
\text { L. }\end{array}$ & Parsley-piert & * & - & 1900 & 2 & 2 \\
\hline Rosa sp. & Rosa canina L. & Dog Roses & $?$ & 23 & 1900 & 1 & 7 \\
\hline Prunus sp. & Prunus Iusitanica L. & & $?$ & & 1904 & 1 & 1 \\
\hline Prunus sp. & Prunus spinosa & Sloe & $?$ & 23 & & 2 & 110 \\
\hline Prunus spinosa L. & $\begin{array}{l}\text { Crataegus } \\
\text { oxyacantha }\end{array}$ & Sloe & $!$ & & & 1 & 1 \\
\hline Prunus spinosa L. & Prunus spinosa & Sloe & & 23 & & 1 & 43 \\
\hline Prunus spinosa L. & Prunus domestica & Sloe & $!$ & & & 1 & 19 \\
\hline $\begin{array}{l}\text { Prunus domestica ssp. } \\
\text { insititia (L.) Bonnier \& } \\
\text { Layens }\end{array}$ & Prunus domestica L. & Bullace/Plum & & & & 1 & 12 \\
\hline
\end{tabular}




\begin{tabular}{|c|c|c|c|c|c|c|c|}
\hline Prunus avium/cerasus & $\begin{array}{l}\text { Crataegus } \\
\text { oxyacantha L. }\end{array}$ & Sweet/dwarf cherry & $!$ & & 1900 & 2 & 1 \\
\hline Pyrus/Malus & Pyrus Malus L. & Pear/Apple & & 23 & 1900 & 1 & 1 \\
\hline Malus sp. & Pyrus Malus L. & Apple & & 23 & 1900 & 2 & 11 \\
\hline Mespilus germanica L. & Pyrus germanica L. & Medlar & * & & 1904 & 2 & 2 \\
\hline Ilex aquifolium L. (leaf) & Ilex aquifolium & Holly & & & 1905 & 1 & 2 \\
\hline $\begin{array}{l}\text { Buxus sempervirens L. } \\
\text { (leaf) }\end{array}$ & Buxus sempervirens & Box & & & 1902 & 2 & 5 \\
\hline Vitis vinifera $\mathrm{L}$. & Vitis vinifera $\mathrm{L}$. & Grape & & 23 & 1900 & 1 & 3 \\
\hline Hydrocotyle vulgaris $\mathrm{L}$. & $\begin{array}{l}\text { Hydrocotyle vulgaris } \\
\text { L. }\end{array}$ & Marsh Pennywort & & & 1900 & 1 & 3 \\
\hline $\begin{array}{l}\text { Anthriscus caucalis M. } \\
\text { Bieb }\end{array}$ & $\begin{array}{l}\text { Caucalis anthriscus } \\
\text { Huds. }\end{array}$ & Bur Chervil & * & & $\begin{array}{l}1902 \\
1908\end{array}$ & 2 & 2 \\
\hline $\begin{array}{l}\text { Scandix pecten-veneris } \\
\text { L. }\end{array}$ & $\begin{array}{l}\text { Chaerophyllum } \\
\text { aureum L. }\end{array}$ & Shepherd's-needle & $!$ & & & 1 & 1 \\
\hline Coriandrum sativum L. & Coriandrum sativum & Coriander & & 21 & 1900 & 1 & 7 \\
\hline $\begin{array}{l}\text { Conopodium majus } \\
\text { (Gouan) Loret }\end{array}$ & $\begin{array}{l}\text { Conopodium } \\
\text { denudatum Kock }\end{array}$ & Pig-nut & * & & & 1 & 1 \\
\hline $\begin{array}{l}\text { Oenanthe pimpinelloides } \\
\text { gp. }\end{array}$ & Oenanthe & Water-dropwort & & & 1900 & 1 & 1 \\
\hline $\begin{array}{l}\text { Oenanthe pimpinelloides } \\
\text { gp. }\end{array}$ & $\begin{array}{l}\text { Oenanthe fistulosa } \\
\text { L. }\end{array}$ & Water-dropwort & $?$ & & 1907 & 1 & 1 \\
\hline $\begin{array}{l}\text { Oenanthe pimpinelloides } \\
\text { gp. }\end{array}$ & Oenanthe lachenalii & Water-dropwort & $?$ & & 1908 & 1 & 1 \\
\hline $\begin{array}{l}\text { Oenanthe pimpinelloides } \\
\text { gp. }\end{array}$ & $\begin{array}{l}\text { Oenanthe lachenalli } \\
\text { or croccoata }\end{array}$ & Water-dropwort & $?$ & & 1900 & 1 & 1 \\
\hline Anethum graveolens $\mathrm{L}$. & $\begin{array}{l}\text { Anethum graveolens } \\
\text { L. }\end{array}$ & Dill & & 23 & $\begin{array}{l}1900 \\
1902, \\
1904\end{array}$ & 5 & 13 \\
\hline Conium maculatum $\mathrm{L}$. & $\begin{array}{l}\text { Conium maculatum } \\
\text { Linn. }\end{array}$ & Hemlock & & $\begin{array}{l}22,23, \\
26\end{array}$ & & 3 & 10 \\
\hline $\begin{array}{l}\text { Apium nodiflorum (L.) } \\
\text { Lag. }\end{array}$ & $\begin{array}{l}\text { Apium nodiflorum } \\
\text { Reichb. }\end{array}$ & Fool's water cress & & 34 & $\begin{array}{l}1902, \\
1906\end{array}$ & 2 & 12 \\
\hline Daucus carota L. & Daucus carota L. & Carrots & & & 1902 & 2 & 2 \\
\hline Apiaceae indet. & Apium graveolens L. & Wild celery & $?$ & 23 & 1900 & 1 & - \\
\hline Hyoscyamus niger L. & Atropa belladonna $L$. & Deadly Nightshade & $!$ & & 1900 & 1 & 1 \\
\hline Hyoscyamus niger L. & $\begin{array}{l}\text { Solanum dulcamara } \\
\text { L. }\end{array}$ & Henbane & $!$ & & - & 1 & 1 \\
\hline Atropa belladonna L. & Atropa belladonna L. & Deadly nightshade & & & 1902 & 3 & 3 \\
\hline Solanum nigrum L. & Solanum nigrum L. & Black Nightshade & & & 1902 & 1 & 5 \\
\hline $\begin{array}{l}\text { cf. Lithospermum } \\
\text { arvense L. }\end{array}$ & $\begin{array}{l}\text { Lithospermum } \\
\text { arvense L. }\end{array}$ & Field Gromwell & $?$ & & 1902 & 1 & 1 \\
\hline Stachys sp. & Stachys arvensis L. & Woundworts & $?$ & & $\begin{array}{l}1902, \\
1903\end{array}$ & 2 & 4 \\
\hline Ballota nigra L. & Ballota nigra L. & Black Horehound & & 23 & & 2 & 6 \\
\hline Lamium sp. & $\begin{array}{l}\text { Lamium purpurium } \\
\text { L. }\end{array}$ & Dead-nettles & $?$ & & 1903 & 1 & 1 \\
\hline Galeopsis tetrahit agg. & Galeopsis tetrahit $\mathrm{L}$. & Common Hemp-nettle & & 6 & $\begin{array}{l}1900 \\
1905\end{array}$ & 4 & 7 \\
\hline Ajuga reptans $\mathrm{L}$. & Ajuga reptans L. & Bugle & & - & 1902 & 1 & 1 \\
\hline Prunella vulgaris L. & Prunella vulgaris $\mathrm{L}$. & Self Heal & & 22 & 1905 & 3 & 5 \\
\hline Lycopus europaeus L. & $\begin{array}{l}\text { Lycopus europaeus } \\
\text { L. }\end{array}$ & Gypsywort & & & $\begin{array}{l}1900 \\
1903\end{array}$ & 2 & 8 \\
\hline Mentha sp. & $\begin{array}{l}\text { Calamintha arvensis } \\
\text { Linn. }\end{array}$ & Mints & ! & & 1902 & 1 & 1 \\
\hline Plantago lanceolata L. & $\begin{array}{l}\text { Plantago lanceolata } \\
\text { L. }\end{array}$ & Ribwort Plantain & & 25 & 1900 & 1 & 1 \\
\hline Veronica hederifolia L. & $\begin{array}{l}\text { Veronica } \\
\text { hederaefolia L. }\end{array}$ & Ivy-leaved speedwell & & 23 & 1900 & 1 & 1 \\
\hline Galium cf. verum L. & Galium verum Linn. & Lady's Bedstraw & $?$ & & 1902 & 3 & 4 \\
\hline Galium cf. aparine L. & Galium palustre L. & Cleavers & $!$ & & 1902 & 1 & 4 \\
\hline Galium aparine L. & Galium aparine Linn. & Cleavers & & & $\begin{array}{l}1902 \\
1907\end{array}$ & 2 & 1 \\
\hline Galium sp. & Galium palustre L. & & $?$ & & 1902 & 1 & 1 \\
\hline Sambucus nigra L. & Sambucus nigra L. & Elder & & & 1903 & 2 & 8 \\
\hline $\begin{array}{l}\text { Valerianella dentata (L.) } \\
\text { Pollich. }\end{array}$ & $\begin{array}{l}\text { Valerianella dentata } \\
\text { Poll. }\end{array}$ & Narrow-fruit corn salad & & & $\begin{array}{l}1900 \\
1909\end{array}$ & 2 & 2 \\
\hline
\end{tabular}




\begin{tabular}{|c|c|c|c|c|c|c|c|}
\hline Arctium sp. & Arctium lappa L. & Burdocks & $?$ & & 1900 & 1 & 1 \\
\hline Carduus sp. & Carduus nutans L. & Thistle & $?$ & & 1902 & 2 & 5 \\
\hline cf. Carduus sp. & Carduus crispus L. & Thistle & $?$ & & 1906 & 1 & 2 \\
\hline Cirsium sp. & $\begin{array}{l}\text { Cricus lanceolatus } \\
\text { Hoffn. }\end{array}$ & Thistles & $?^{*}$ & 22 & & 1 & 4 \\
\hline Cirsium sp. & $\begin{array}{l}\text { Cricus palustris } \\
\text { Hoffn }\end{array}$ & Thistles & $?^{*}$ & 6 & 1905 & 1 & 2 \\
\hline Cirsium sp. & $\begin{array}{l}\text { Crisus arvensis } \\
\text { Hoffn. }\end{array}$ & Thistles & $?^{*}$ & & 1902 & 3 & 5 \\
\hline $\begin{array}{l}\text { Onopordum acanthium } \\
\text { L. }\end{array}$ & $\begin{array}{l}\text { Onopordum } \\
\text { acanthium L. }\end{array}$ & Cotton Thistle & & & 1905 & 1 & 1 \\
\hline Centaurea nigra L. & Centaurea nigra L. & Common Knapweed & & & 1902 & 2 & 2 \\
\hline Lapsana communis L. & $\begin{array}{l}\text { Lapsana communis } \\
\text { L. }\end{array}$ & Nipple wort & & & 1902 & 1 & 2 \\
\hline Hypochaeris sp. & $\begin{array}{l}\text { Hypochaeris } \\
\text { radicata }\end{array}$ & Cat's-ears & $?$ & & 1907 & 1 & 1 \\
\hline Leontodon sp. & Sonchus palustris $\mathrm{L}$. & Hawkbits & $!$ & & 1902 & 1 & 3 \\
\hline Leontodon sp. & Leontodon hispidus & Hawkbits & $?$ & & $\begin{array}{l}1900 \\
1905\end{array}$ & 1 & 4 \\
\hline Sonchus oleraceus L. & $\begin{array}{l}\text { Sonchus oleraceus } \\
\text { L. }\end{array}$ & Smooth Sowthistle & & 23 & $\begin{array}{l}1900 \\
1902\end{array}$ & 2 & 3 \\
\hline Sonchus asper (L.) Hill & $\begin{array}{l}\text { Sonchus asper } \\
\text { Hoffn }\end{array}$ & Prickly Sowthistle & & & $\begin{array}{l}1906, \\
1907\end{array}$ & 2 & 3 \\
\hline Sonchus asper (L.) Hill & $\begin{array}{l}\text { Valeriana officinalis } \\
\text { L. }\end{array}$ & Prickly Sowthistle & $!$ & & & & \\
\hline Sonchus asper (L.) Hill & $\begin{array}{l}\text { Sonchus asper } \\
\text { Hoffn }\end{array}$ & Prickly Sowthistle & & & $\begin{array}{l}1906, \\
1907\end{array}$ & 2 & 3 \\
\hline Taraxacum sp. & Taraxacum officinale & Dandelions & $?$ & & 1909 & 1 & 3 \\
\hline $\begin{array}{l}\text { Leucanthemum vulgare } \\
\text { Lam. }\end{array}$ & $\begin{array}{l}\text { Chrysanthemum } \\
\text { leucanthemum } \mathrm{L} \text {. }\end{array}$ & Oxeye Daisy & * & & $\begin{array}{l}1900 \\
1902\end{array}$ & 3 & 2 \\
\hline Bidens tripartita L. & Bidens tripartita L. & Trfid Bur-marigold & & & $\begin{array}{l}1900 \\
1903\end{array}$ & 2 & 2 \\
\hline $\begin{array}{l}\text { Alisma plantago- } \\
\text { aquatica L. }\end{array}$ & Alisma plantago L. & Water-plantain & * & - & 1905 & 1 & 1 \\
\hline Potamogetan sp. & Potamogetan & & & & 1909 & 1 & 5 \\
\hline $\begin{array}{l}\text { Eleocharis palustris (L.) } \\
\text { Roem. \& Schult. agg. }\end{array}$ & $\begin{array}{l}\text { Eleocharis palustris } \\
\mathrm{R} . \mathrm{Br} \text { - }\end{array}$ & Common spike-rush & & & 1903 & 2 & 5 \\
\hline Cyperaceae indet. & Carex dioica L. & Sedge family & ? & & 1902 & 1 & 1 \\
\hline Carex sp. & Carex & Sedge & & 22 & 1899 & 1 & 1 \\
\hline Carex sp. & Carex muricata Linn. & Sedge & $?$ & & 1903 & 1 & 1 \\
\hline Carex sp. & $\begin{array}{l}\text { Carex ovalis ? } \\
\text { Good. }\end{array}$ & Sedge & $?$ & & 1902 & 1 & 1 \\
\hline Carex sp. & Carex panicea ? L. & Sedge & $?$ & & 1903 & 1 & 1 \\
\hline Carex sp. & $\begin{array}{l}\text { Carex remota? } \\
\text { Linn. }\end{array}$ & Sedge & $?$ & & & 1 & - \\
\hline Carex sp. & Carex riparia Curtis & Sedge & $?$ & & $\begin{array}{l}1900 \\
1902\end{array}$ & 2 & 3 \\
\hline Sparganium sp. & $\begin{array}{l}\text { Spharganium } \\
\text { simplex }\end{array}$ & Bur-reeds & $?$ & & 1909 & 2 & 7 \\
\hline Sparganium erectum $\mathrm{L}$. & $\begin{array}{l}\text { Sparganium } \\
\text { ramosum/erectum }\end{array}$ & Branched Bur-reed & & & 1909 & 1 & 1 \\
\hline Seed indet. & $\begin{array}{l}\text { Plantago lanceolata } \\
\text { L. }\end{array}$ & & & & 1905 & 1 & 2 \\
\hline Fungal body & Brassica alba Boiss. & & $!$ & 22 & - & 1 & 7 \\
\hline $\begin{array}{l}\text { Pteridium aquilinium (L.) } \\
\text { Kuhn (frond) }\end{array}$ & Pteris aquilina $\mathrm{L}$. & Bracken & & & $\begin{array}{l}1900 \\
1909\end{array}$ & 4 & 4 \\
\hline $\begin{array}{l}\text { Rubus fruticosus agg. } \\
\text { (stem) }\end{array}$ & Rubus fruticosus $\mathrm{L}$. & Blackberry & & & 1903 & 1 & 2 \\
\hline 盗 & $\begin{array}{l}\text { Ranunculus } \\
\text { scleratus L. }\end{array}$ & & & & $\begin{array}{l}1900 \\
1906\end{array}$ & 2 & 3 \\
\hline- & Papaver rhoeas L. & Common Poppy & & & & 1 & - \\
\hline- & $\begin{array}{l}\text { Stellaria uliginosa } \\
\text { Murray }\end{array}$ & Bog Stichwort & & & 1905 & 2 & - \\
\hline- & $\begin{array}{l}\text { Lychnis flos-cuculi } \\
\text { Linn. }\end{array}$ & & & & & 1 & - \\
\hline- & Lychnis alba Mill & & & & & 1 & - \\
\hline- & Polygonum & & & & 1900 & 1 & - \\
\hline- & Potentilla & & & & & 1 & - \\
\hline
\end{tabular}




\begin{tabular}{|c|c|c|c|c|c|c|c|}
\hline- & Galium & & & & & 1 & - \\
\hline- & Sonchus palustris L. & & & & 1900 & & \\
\hline \multicolumn{8}{|l|}{ Unlabelled items } \\
\hline Pinus pinea L. & & Stone pine (cone) & & & & 2 & $\begin{array}{l}2 \text { ( } 1 \\
\text { frag } \\
\text { men } \\
\text { ted) }\end{array}$ \\
\hline Prunus spinosa L. & & Sloe & & & & 8 & 198 \\
\hline Prunus domestica L. & & Bullace/Plum & & & & 1 & 1 \\
\hline $\begin{array}{l}\text { Prunus domestica ssp. } \\
\text { domestica L. }\end{array}$ & & Plum & & & & 1 & 14 \\
\hline $\begin{array}{l}\text { Prunus domestica ssp. } \\
\text { insititia (L.) Bonnier \& } \\
\text { Layens }\end{array}$ & & Bullace/Damson & & & & 8 & 73 \\
\hline $\begin{array}{l}\text { Prunus cf. domestica } \\
\text { ssp. insititia L. }\end{array}$ & & Bullace/Damson & & & & 1 & 3 \\
\hline Prunus avium (L.) L. & & Sweet cherry & & & & 5 & 67 \\
\hline Prunus cf. avium L. & & Sweet cherry & & & & 1 & 2 \\
\hline Prunus sp. & & Cherry/Plum etc. & & & & 3 & 19 \\
\hline Pyrus/Malus sp. & & Pear/Apple & & & & 1 & 3 \\
\hline \multicolumn{8}{|l|}{ Mineralised } \\
\hline Anethum graveolens $\mathrm{L}$. & $\begin{array}{l}\text { Anethum graveolens } \\
\text { L. }\end{array}$ & Dill & & & $\begin{array}{l}1900, \\
1903\end{array}$ & 2 & 4 \\
\hline Prunus avium (L.) L. & - & Sweet Cherry & & & & 2 & 19 \\
\hline Prunus sp. & - & Cherry/Plum etc. & & & & 2 & 15 \\
\hline \multicolumn{8}{|l|}{ Charred } \\
\hline Triticum spelta L. (grain) & Triticum sativum L. & Spelt wheat & $!$ & 23 & 1903 & 1 & 1 \\
\hline Triticum sp. (grain) & Triticum sativum $\mathrm{L}$. & Wheat & $?$ & 23,27 & 1903 & 1 & 3 \\
\hline $\begin{array}{l}\text { Triticum spelta/dicoccum } \\
\text { (grain) }\end{array}$ & Triticum sativum $\mathrm{L}$. & Spelt/emmer wheat & $!$ & 27 & & 2 & 2 \\
\hline Cereal indet. (grain) & Triticum sativum $\mathrm{L}$. & & $?$ & 23 & 1900 & 1 & 2 \\
\hline cf. Bromus secalinus L. & Triticum sativum L. & Rye brome & $!$ & 27 & & 1 & 1 \\
\hline Vicia faba var. minor L. & - & Celtic Bean & & & & 1 & 14 \\
\hline
\end{tabular}


Table 3: Summary of plant foods confirmed from the Reading Museum Silchester Collection (R), and those published in Archaeologia (A), listed by year and area of excavation.

\begin{tabular}{|c|c|c|c|c|c|c|c|c|c|c|}
\hline Year published & 1901 & 1902 & 1903 & 1905 & 1906 & 1907 & 1908 & 1909 & - & $\begin{array}{l}\text { No } \\
\text { date }\end{array}$ \\
\hline Year excavated & $\begin{array}{l}1899 \\
- \\
1900\end{array}$ & 1901 & 1902 & $\begin{array}{l}1903- \\
4\end{array}$ & 1905 & 1906 & 1907 & 1908 & 1909 & $\begin{array}{l}\text { No } \\
\text { date }\end{array}$ \\
\hline Insulae & $\begin{array}{l}\text { XXIII } \\
\text { XXI, } \\
X X V, \\
X X V I\end{array}$ & $\begin{array}{l}\text { XXII, } \\
\text { XXVII }\end{array}$ & $\begin{array}{l}\text { XXX, } \\
\text { XXIX, } \\
\text { XXXI, } \\
\text { XXXII }\end{array}$ & XXIII & $\mathrm{V}, \mathrm{VI}$ & XXXIV & $\begin{array}{l}X X V I I I \\
X X X V\end{array}$ & $\begin{array}{l}\text { XXIX, } \\
\text { XXXVI } \\
\text { XXXVI } \\
\text { I }\end{array}$ & $\begin{array}{l}\text { City } \\
\text { walls }\end{array}$ & - \\
\hline \multicolumn{11}{|l|}{ Cultivated plants } \\
\hline Bullace/Damson & A & $R$ & & $\mathrm{R}$ & & & $\mathrm{R}$ & & $\mathrm{R}$ & $\mathrm{R}$ \\
\hline Celery & $A$ & & & & & & & & & \\
\hline Celtic Bean & & & & & & & & & & $R$ \\
\hline Coriander & AR & & & & & & & & & \\
\hline Dill & $R$ & & $R$ & $\mathrm{R}$ & $A$ & & & & & $\mathrm{R}$ \\
\hline Fig & AR & & $\mathrm{R}$ & & & & $A$ & & & \\
\hline Flax & & A & & & & & & & & \\
\hline Flax (capsule) & $A$ & & & & & & & & & \\
\hline Grape & AR & & & & & & & & & \\
\hline Medlar & & & & AR & & & & & & \\
\hline Mulberry & & & $\mathrm{AR}$ & & & & & & & \\
\hline Pea & & & & & & & $A$ & & & \\
\hline Pear/Apple & $\mathrm{AR}$ & & & $\mathrm{R}$ & & & $A$ & & & $\mathrm{R}$ \\
\hline Plum & $A$ & & & $A$ & & & AR & & $\mathrm{R}$ & $\mathrm{R}$ \\
\hline Raspberry & $A$ & & & & & & & & & \\
\hline $\begin{array}{l}\text { Stone pine } \\
\text { (bracts/nutshell) }\end{array}$ & & & & & & & & & & $\mathrm{R}$ \\
\hline Sweet Cherry & $A$ & $\mathrm{R}$ & & $\mathrm{R}$ & & & AR & & $\mathrm{R}$ & $\mathrm{R}$ \\
\hline \multicolumn{11}{|l|}{ Wild plants } \\
\hline Black Mustard & & & & & & $R$ & $\mathrm{R}$ & & & \\
\hline Brassica sp. & $\mathrm{R}$ & AR & & & & $R$ & & & & \\
\hline Hazelnut (nutshell) & A & & & & & & & & & \\
\hline Hawthorn & $A$ & & & & & & & & & \\
\hline Wild strawberry & $A$ & & & & & & & & & \\
\hline Prunus sp. & & $A$ & & & & & & & & $R$ \\
\hline Sloe & $A R$ & $\mathrm{R}$ & & $R$ & & & $A R$ & & $R$ & $R$ \\
\hline Blackberry & A & $A R$ & & & & & $A$ & & & $\mathrm{R}$ \\
\hline Elder & $A$ & $A$ & & $\mathrm{R}$ & & & & & & $R$ \\
\hline
\end{tabular}


Table 4: Summary of archaeophytes confirmed from the Reading Museum Silchester Collection $(R)$, and those published in Archaeologia (A), listed by year and area of excavation.

\begin{tabular}{|c|c|c|c|c|c|c|c|c|c|}
\hline Year published & 1901 & 1902 & 1903 & 1905 & 1906 & 1907 & 1908 & 1909 & - \\
\hline Year excavated & $\begin{array}{l}1899 \\
-1900\end{array}$ & 1901 & 1902 & $\begin{array}{l}1903- \\
4\end{array}$ & 1905 & 1906 & 1907 & 1908 & 1909 \\
\hline Insulae & $\begin{array}{l}\text { XXIII } \\
\text { XXI, } \\
\text { XXV, } \\
\text { XXVI }\end{array}$ & $\begin{array}{l}\text { XXII, } \\
\text { XXVII }\end{array}$ & $\begin{array}{l}\text { XXX, } \\
\text { XXIX, } \\
\text { XXXI, } \\
\text { XXXII }\end{array}$ & XXIII & $\mathrm{V}, \mathrm{VI}$ & XXXIV & $\begin{array}{l}x X V I I I \\
x x x V\end{array}$ & $\begin{array}{l}\text { XXIX, } \\
\text { XXXVI } \\
\text { XXXVI } \\
\text { XXVI }\end{array}$ & $\begin{array}{l}\text { City } \\
\text { walls }\end{array}$ \\
\hline $\begin{array}{l}\text { Chenopodium } \\
\text { hybridum L. }\end{array}$ & & & $A R$ & & & & & & \\
\hline $\begin{array}{l}\text { Agrostemma githago } \\
\text { L. }\end{array}$ & $A R$ & & & & & & & & \\
\hline $\begin{array}{l}\text { Coronopus } \\
\text { squamatus (Forssk.) } \\
\text { Asch. }\end{array}$ & AR & $\mathrm{R}$ & & & & & & & \\
\hline $\begin{array}{l}\text { Scandix pecten- } \\
\text { veneris L. }\end{array}$ & & & & & & & AR & & \\
\hline $\begin{array}{l}\text { Onopordum } \\
\text { acanthium } \mathrm{L} .\end{array}$ & & & & & $A R$ & & & & \\
\hline
\end{tabular}




\section{Figure Captions}

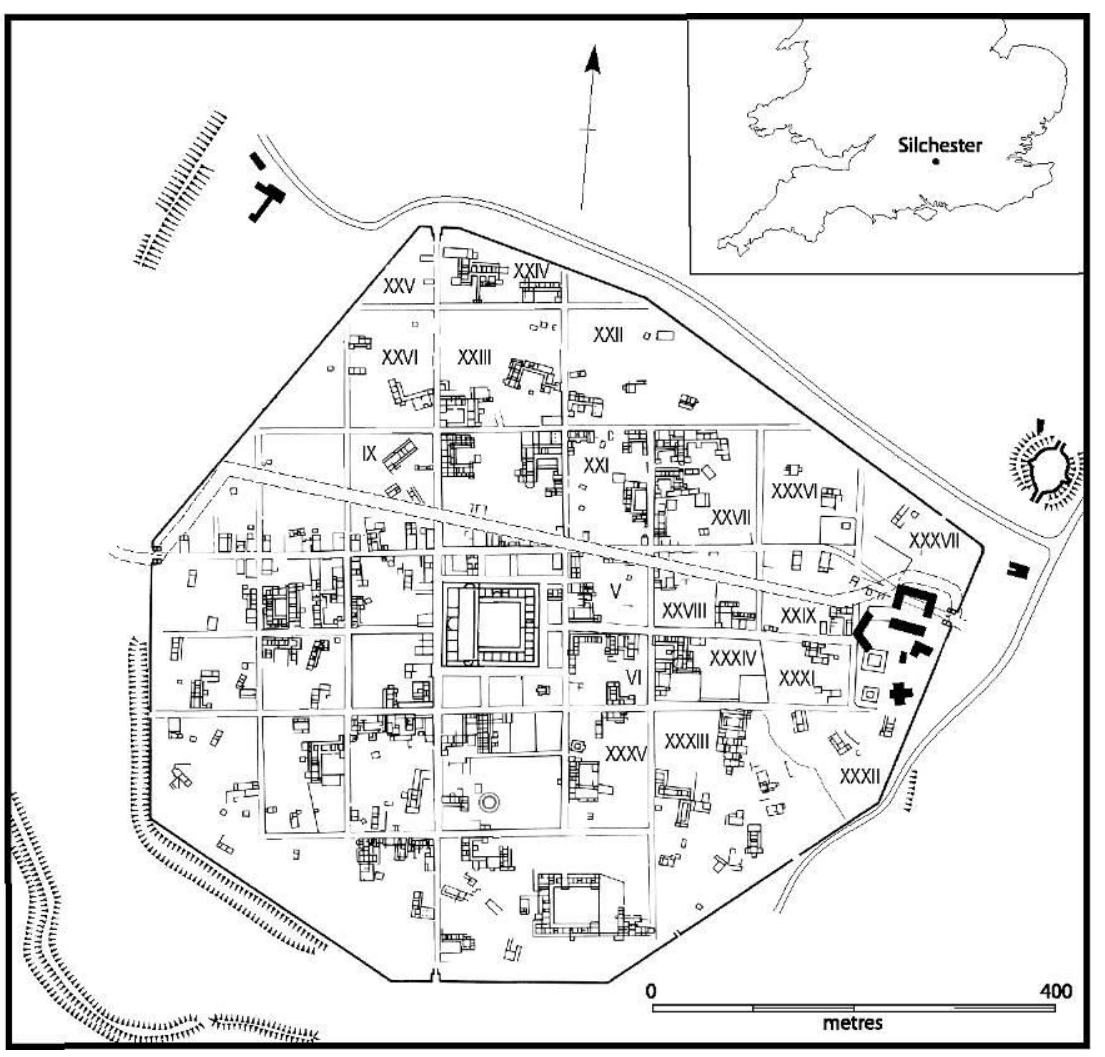

Figure 1: Victorian plan of Silchester indicating Insulae studied for archaeobotanical remains.

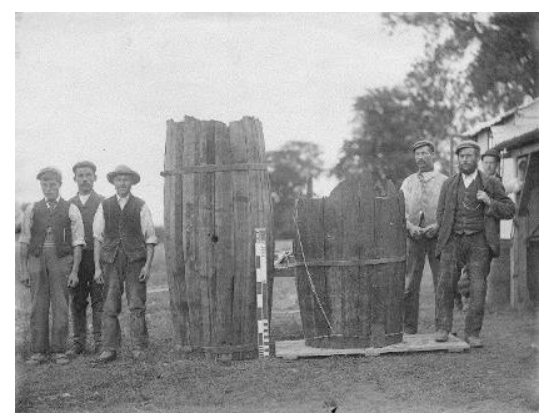

Figure 2: Photograph of a group of excavators with two wooden barrels found in wells in Insulae XVII and XVIII, 1897 (Reading Museum (Reading Borough Council) CC BY-NC license)). 
Image not available due to copyright.

Figure 3: Fungal bodies, identified by Reid as Brassica alba ? Boiss. from a well in Insula 22. Copyright Reading Museum (Reading Borough Council). All rights reserved.

Image not available due to copyright.

Figure 4: Prunus sp., identified by Reid as Prunus lusitanica L. from the 1903 excavations. Copyright Reading Museum (Reading Borough Council). All rights reserved.

Image not available due to copyright.

Figure 5: Coriandrum sativum, identified by Reid as Coriandrum sativum L. from the 1900 excavations. Copyright Reading Museum (Reading Borough Council). All rights reserved.

Image not available due to copyright.

Figure 6: Ficus carica, identified by Reid as Ficus carica L. from the 1902 excavations. Copyright Reading Museum (Reading Borough Council). All rights reserved.

Image not available due to copyright.

Figure 7: Mespilus germanica, identified by Reid as Pyrus germanica Linn. from the 1904 excavations. Copyright Reading Museum (Reading Borough Council). All rights reserved. 